National Water Availability and Use Pilot Program

\title{
Implementation of Local Grid Refinement (LGR) for the Lake Michigan Basin Regional Groundwater-Flow Model
}

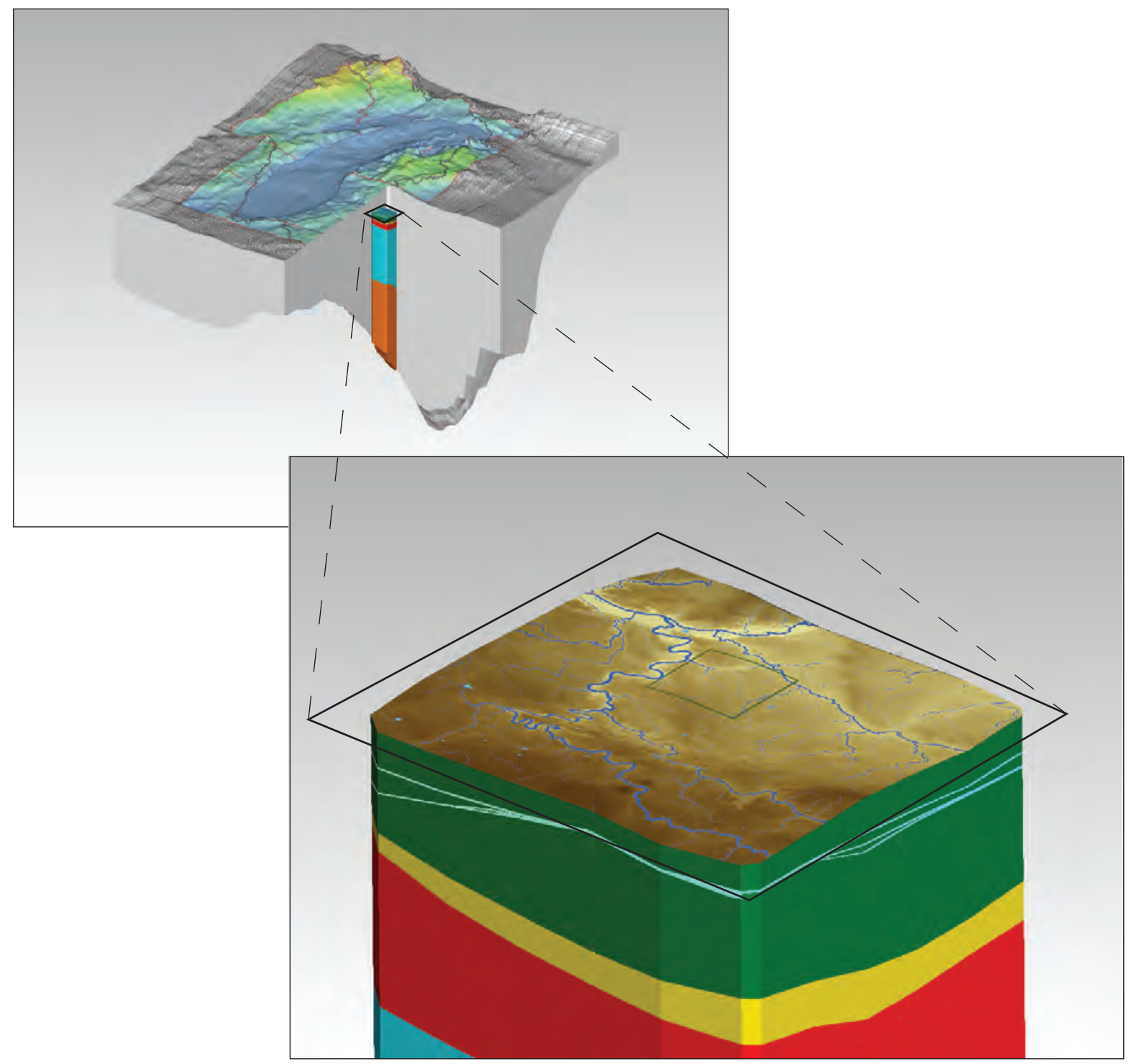

Scientific Investigations Report 2010-5117 



\section{Implementation of Local Grid Refinement (LGR) for the Lake Michigan Basin Regional Groundwater-Flow Model}

By C.J. Hoard

National Water Availability and Use Pilot Program

Scientific Investigations Report 2010-5117 


\section{U.S. Department of the Interior \\ KEN SALAZAR, Secretary}

\section{U.S. Geological Survey \\ Marcia K. McNutt, Director}

\section{U.S. Geological Survey, Reston, Virginia 2010}

For product and ordering information:

World Wide Web: http://www.usgs.gov/pubprod

Telephone: 1-888-ASK-USGS

For more information on the USGS - the Federal source for science about the Earth, its natural and living resources, natural hazards, and the environment:

World Wide Web: http://www.usgs.gov

Telephone: 1-888-ASK-USGS

Suggested citation:

Hoard, C.J., 2010, Implementation of local grid refinement (LGR) for the Lake Michigan Basin regional groundwater-flow model: U.S. Geological Survey Scientific Investigations Report 2010-5117, 25 p.

Any use of trade, product, or firm names is for descriptive purposes only and does not imply endorsement by the U.S. Government.

Although this report is in the public domain, permission must be secured from the individual copyright owners to reproduce any copyrighted material contained within this report. 


\section{Contents}

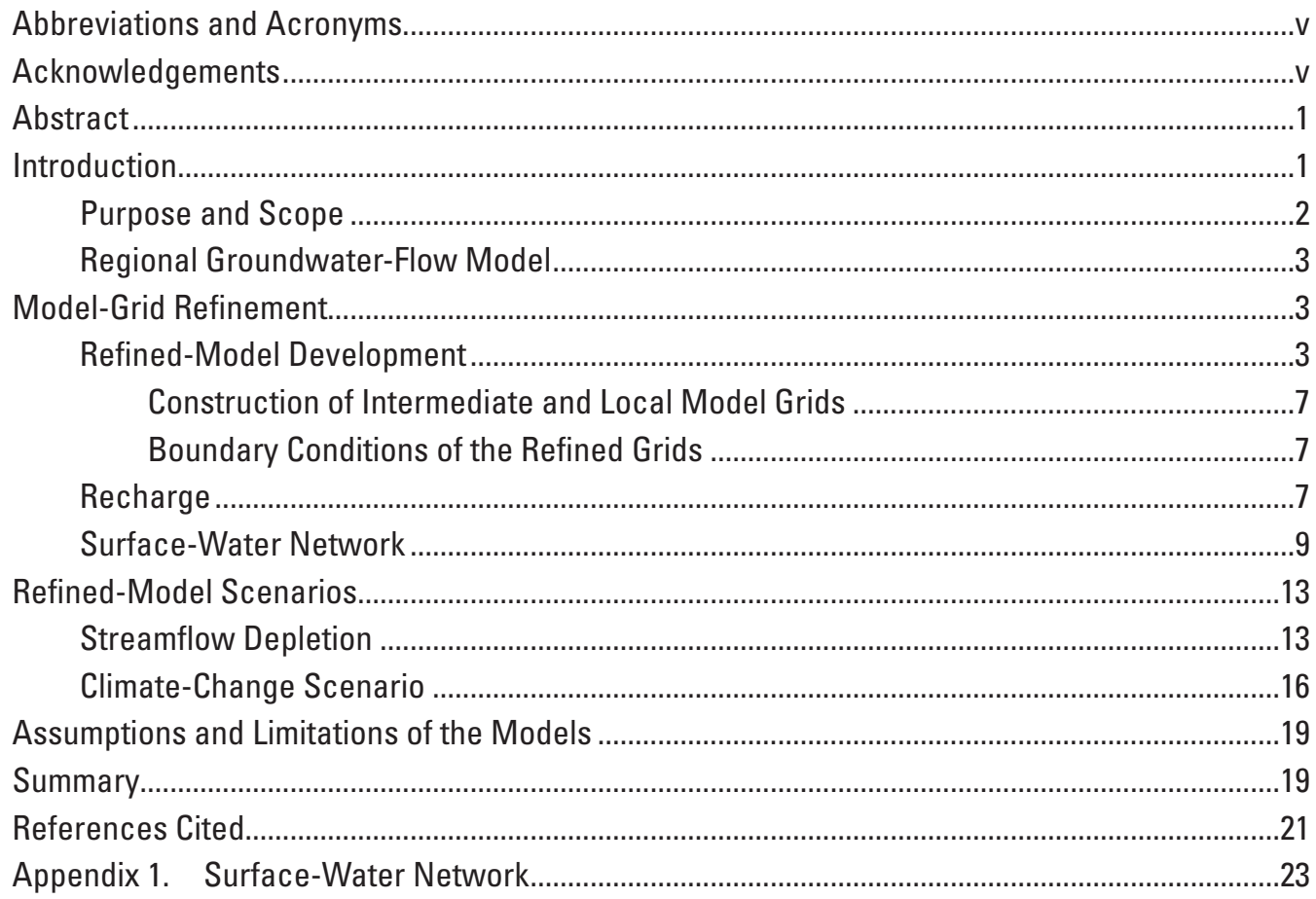

\section{Figures}

1. Location and features of the regional, intermediate, and local models.............................4

2. Geologic cross sections for the regional and local models .................................................5

3. Example of shared-node distribution between the intermediate and local models .........8

4. Seasonal distribution of recharge for the adjusted and non-adjusted recharge values

5. Surface-water network for the area of the local model shown in comparison to how it was discretized at the levels of grid refinement used in the regional and intermediate models.

6. Stream network for the intermediate- and local-model areas..............................................12

7. Location of test watershed, test stream, stream gage, and pumped well for refined-model scenarios ...................................................................................................... 14

8. Hydrographs of test stream for streamflow-depletion scenarios ......................................15

9. Distribution of the source of water to the pumping well for the stream-depletion scenarios

10. Recharge and streamflow distribution shown for three time periods for the test stream in the climate-change scenario. 


\section{Tables}

1. Summary of physical properties used for the intermediate model ....................................6

2. Summary of physical properties used for the local model ...............................................6

3. Summary of the overall water budget in the test watershed with a well pumping in layer 1

\section{Appendix figures}

1-1. Stream-segment construction across the intermediate and local-model boundary

\section{Conversion Factors}

\begin{tabular}{|c|c|c|}
\hline Multiply & By & To obtain \\
\hline \multicolumn{3}{|c|}{ Length } \\
\hline foot $(\mathrm{ft})$ & 0.3048 & meter $(\mathrm{m})$ \\
\hline meter $(\mathrm{m})$ & 3.281 & foot $(\mathrm{ft})$ \\
\hline mile (mi) & 1.609 & kilometer $(\mathrm{km})$ \\
\hline \multicolumn{3}{|c|}{ Area } \\
\hline square foot $\left(\mathrm{ft}^{2}\right)$ & 0.09290 & square meter $\left(\mathrm{m}^{2}\right)$ \\
\hline square mile $\left(\mathrm{mi}^{2}\right)$ & 259.0 & hectare (ha) \\
\hline square mile $\left(\mathrm{mi}^{2}\right)$ & 2.590 & square kilometer $\left(\mathrm{km}^{2}\right)$ \\
\hline \multicolumn{3}{|c|}{ Volume } \\
\hline gallon (gal) & 3.785 & liter $(\mathrm{L})$ \\
\hline gallon (gal) & 0.003785 & cubic meter $\left(\mathrm{m}^{3}\right)$ \\
\hline million gallons (Mgal) & 3,785 & cubic meter $\left(\mathrm{m}^{3}\right)$ \\
\hline cubic foot $\left(\mathrm{ft}^{3}\right)$ & 0.02832 & cubic meter $\left(\mathrm{m}^{3}\right)$ \\
\hline \multicolumn{3}{|c|}{ Flow rate } \\
\hline cubic foot per second $\left(\mathrm{ft}^{3} / \mathrm{s}\right)$ & 0.02832 & cubic meter per second $\left(\mathrm{m}^{3} / \mathrm{s}\right)$ \\
\hline cubic foot per day $\left(\mathrm{ft}^{3} / \mathrm{d}\right)$ & 0.02832 & cubic meter per day $\left(\mathrm{m}^{3} / \mathrm{d}\right)$ \\
\hline gallon per minute (gal/min) & 0.06309 & liter per second $(\mathrm{L} / \mathrm{s})$ \\
\hline million gallons per day (Mgal/d) & 0.04381 & cubic meter per second $\left(\mathrm{m}^{3} / \mathrm{s}\right)$ \\
\hline \multicolumn{3}{|c|}{ Hydraulic conductivity } \\
\hline foot per day $(\mathrm{ft} / \mathrm{d})$ & 0.3048 & meter per day $(\mathrm{m} / \mathrm{d})$ \\
\hline \multicolumn{3}{|c|}{ Hydraulic gradient } \\
\hline foot per mile (ft/mi) & 0.1894 & meter per kilometer $(\mathrm{m} / \mathrm{km})$ \\
\hline
\end{tabular}

Vertical coordinate information is referenced to the North American Vertical Datum of 1988 (NAVD 88).

Horizontal coordinate information is referenced to the North American Datum of 1983 (NAD 83).

Elevation, as used in this report, refers to distance above the vertical datum.

Concentrations of chemical constituents in water are given in milligrams per liter (mg/L). 


\title{
Abbreviations and Acronyms
}

\author{
AFINCH Analysis of Flows in Networks of Channels \\ AOGCM Atmosphere Ocean Coupled General Circulation Model \\ CMIP3 Coupled Model Intercomparison Project 3 \\ DEM Digital Elevation Model \\ GHB General Head Boundary Package \\ GIS Geographic Information System \\ GLBP Great Lakes Basin Pilot \\ HUC Hydrologic Unit Code \\ LGR Local Grid Refinement \\ LPF Layer Property Flow Package \\ NHD National Hydrography Dataset \\ PCMDI Program for Climate Model Diagnosis and Intercomparison \\ SFR1 Streamflow Routing Package \\ SWB Soil Water Balance \\ TMR Telescopic Mesh Refinement \\ USGS United States Geological Survey \\ WCRP World Climate Research Programs \\ WGCM Working Group on Coupled Modelling
}

\section{Acknowledgments}

The author wishes to acknowledge the modeling groups, the Program for Climate Model Diagnosis and Intercomparison (PCMDI) and the World Climate Research Programs (WCRP) Working Group on Coupled Modelling (WGCM) for their roles in making available the WCRP Coupled Model Intercomparison Project 3 (CMIP3) multi-model dataset. Support of this dataset is provided by the Office of Science, U.S. Department of Energy. Additional simulations provided courtesy of Katherine Hayhoe, Edwin Maurer, and Jeff VanDorn of ATMOS Research and Consulting.

The author also wishes to thank Daniel Feinstein, Mike Fienen, Randy Hunt, Steffen Mehl, Howard Reeves, and Steve Westenbroek from the USGS for the assistance in planning and developing the various simulations described in this report. Jesse Dickinson and Connor Haugh, also from the USGS, provided thorough technical reviews of this report. A complete editorial review of this report was provided by Bonnie Fink (USGS ). 



\title{
Implementation of Local Grid Refinement (LGR) for the Lake Michigan Basin Regional Groundwater-Flow Model
}

\author{
By C.J. Hoard
}

\section{Abstract}

The U.S. Geological Survey is evaluating water availability and use within the Great Lakes Basin. This is a pilot effort to develop new techniques and methods to aid in the assessment of water availability. As part of the pilot program, a regional groundwater-flow model for the Lake Michigan Basin was developed using SEAWAT-2000. The regional model was used as a framework for assessing local-scale water availability through grid-refinement techniques. Two gridrefinement techniques, telescopic mesh refinement and local grid refinement, were used to illustrate the capability of the regional model to evaluate local-scale problems. An intermediate model was developed in central Michigan spanning an area of 454 square miles $\left(\mathrm{mi}^{2}\right)$ using telescopic mesh refinement. Within the intermediate model, a smaller local model covering an area of $21.7 \mathrm{mi}^{2}$ was developed and simulated using local grid refinement. Recharge was distributed in space and time using a daily output from a modified Thornthwaite-Mather soil-water-balance method. The soil-water-balance method derived recharge estimates from temperature and precipitation data output from an atmosphere-ocean coupled generalcirculation model. The particular atmosphere-ocean coupled general-circulation model used, simulated climate change caused by high global greenhouse-gas emissions to the atmosphere. The surface-water network simulated in the regional model was refined and simulated using a streamflow-routing package for MODFLOW.

The refined models were used to demonstrate streamflow depletion and potential climate change using five scenarios. The streamflow-depletion scenarios include (1) natural conditions (no pumping), (2) a pumping well near a stream; the well is screened in surficial glacial deposits, (3) a pumping well near a stream; the well is screened in deeper glacial deposits, and (4) a pumping well near a stream; the well is open to a deep bedrock aquifer. Results indicated that a range of 59 to 50 percent of the water pumped originated from the stream for the shallow glacial and deep bedrock pumping scenarios, respectively. The difference in streamflow reduction between the shallow and deep pumping scenarios was compensated for in the deep well by deriving more water from regional sources. The climate-change scenario only simulated natural conditions from 1991-2044, so there was no pumping stress simulated. Streamflows were calculated for the simulated period and indicated that recharge over the period generally increased from the start of the simulation until approximately 2017, and decreased from then to the end of the simulation. Streamflow was highly correlated with recharge so that the lowest streamflows occurred in the later stress periods of the model when recharge was lowest.

\section{Introduction}

In 2005, the U.S. Congress requested the U.S. Geological Survey (USGS) to initiate an assessment of the availability and use of water resources and the factors that affect water resources throughout the United States. The goal of the National Assessment of Water Availability and Use Program is to improve methods for predicting water availability for future economic and environmental uses (Grannemann and Reeves, 2005). This program began as a pilot study within the Great Lakes Basin to develop the tools and methods necessary to study water availability and to disseminate the results. The techniques developed can be used in future studies as the National Assessment of Water Availability and Use Program expands into other areas of the Nation.

As demands on water resources increase, it becomes more important to quantify the water resources available to effectively manage their use. Groundwater and surface water are best treated as a single resource - an important consideration as water-resource managers assess environmental flows, or those flows required to sustain aquatic ecosystems while maintaining anthropogenic uses of the resource (The Nature Conservancy, 2008). The environmental flows in streams reflect the need for a better understanding of stream-aquifer interaction, especially when groundwater withdrawals may affect streamflow- and groundwater-dependent ecosystems.

As part of the Great Lakes Basin Pilot (GLBP) study, a regional groundwater-flow model was constructed for the Lake Michigan Basin (Feinstein and others, in press). The objectives of the regional model were to provide (1) a forecasting tool to assess regional effects of water use and climate in the western portion of the Great Lakes Basin; (2) a platform 
for developing embedded, higher-resolution models that can be used to address water-management issues at local scales; (3) a means of documenting and archiving information from a wide variety of sources on the hydrogeology and water use in the region; and (4) a basis for developing indicators of sustainability of water resources (Feinstein and others, in press). The results of this modeling effort have yielded (1) improved estimates of the various components of the water budget for the region; (2) synthesis and improved estimates of the various hydraulic properties of the geologic units in the region; (3) a better understanding of groundwater flow throughout the region; and (4) a tool for water managers in the region to aid in evaluating the sustainability of water resources.

Although the Lake Michigan Basin groundwater-flow model has provided a tool to assess water availability for the region, the large grid-cell structure needed in the regional model $(5,000$ by $5,000 \mathrm{ft})$ likely is too coarse to address many smaller-scale problems. Regional models are designed to provide answers to questions on a large scale, such as identifying and quantifying the various components of the regional water budget. Often the issues related to groundwater and surfacewater interaction occur at a smaller scale than the size of a model cell in the regional model.

Situations that benefit from improved simulation accuracy obtained from fine grid resolution include, but are not limited to, the assessment of drawdown near pumping centers and the assessment of surface-water and groundwater interaction near streams. Regional models can be refined by variablegrid spacing to achieve small grid sizes in the area of interest, or by global refinement using a small cell size over the whole region, or by locally refining the model through various grid-refinement techniques. Model refinement of the regional model by either of the first two options generates a vast number of cells in the overall model. Although this improves model accuracy, it also leads to lengthy computation time. Using grid-refinement techniques limits the cell refinement to the area of interest, which allows for improved model accuracy only in the area of interest.

Two grid-refinement techniques developed for MODFLOW (Harbaugh, 2005) - telescopic mesh refinement (TMR) (Leake and Claar, 1999) and local grid refinement (LGR) (Mehl and Hill, 2006) - allow for grid refinement using a fine grid "child" model within a coarse grid "parent" model. However, the difference between the two methods is in how the child model is linked to the parent model. With TMR, the coupling between the parent and child model is one way, such that each model is simulated once, and the boundary conditions for the refined model are established using head and flux boundary conditions determined from the parent model; the child model is then run independently. The LGR technique couples the parent and child model in such a way that the models are run sequentially and iterate to a final solution that is a compromise between a more accurate solution by the child model and a less accurate solution by the parent model. Head and flux conditions taken from the parent and used initially along the child boundaries are allowed to change, and as changes occur they are propagated back through to the parent model. The disadvantage of TMR coupling is that changes to the child model are not propagated out to the parent model without user intervention. The primary disadvantage of the LGR approach is the longer runtimes and relatively more complex input requirement. Both TMR and LGR approaches are able to use the streamflow-routing (SFR1) package (Prudic and others, 2004) of MODFLOW to improve the evaluation of stream-aquifer interactions within the model.

As part of the effort to demonstrate the tools and methods available for assessing water availability, grid-refinement techniques were applied to the Lake Michigan Basin regional model. These grid-refinement techniques were used at multiple scales to achieve a model cell size capable of accurately modeling stream-aquifer interactions. Stream-aquifer interactions are of particular importance in evaluating how groundwater withdrawals potentially affect environmental flows. To that end, hypothetical model scenarios of refined portions of the regional model were developed to evaluate the effects of groundwater withdrawals on streams. It should be noted that streamflows required to support specific aquatic habitat were not evaluated as part of this investigation. In addition, hypothetical model scenarios examining the potential effect of climate change on groundwater recharge and the resultant effect on the water resources of the area of interest also were developed.

\section{Purpose and Scope}

The purpose of this report is to describe the use of gridrefinement techniques for MODFLOW to examine local-scale hydrology within a regional model. This modeling effort builds on the regional model developed for the Lake Michigan Basin as part of the GLBP project of the USGS national assessment of water availability and use. Grid refinement was used to demonstrate (1) local-scale groundwater and surfacewater interactions - specifically the effects of groundwater withdrawals on streamflow, and (2) potential climate change effects on water resources at a local scale. Two stages of grid refinement were performed on the regional model: one on an area of $453.8 \mathrm{mi}^{2}$ and another on a smaller subset of the initial refined area of $22.4 \mathrm{mi}^{2}$. The National Hydrography Dataset (NHD) NHDPlus database (Horizon Systems Corporation, 2006) was used to develop the surface-water networks used within the refined model areas. Climate projections based on Hayhoe and others (2008) and Maurer and others (2002) were used to develop recharge estimates for evaluation of climate effects on water resources for a 53-year period (1991-2044). 


\section{Regional Groundwater-Flow Model}

The Lake Michigan Basin regional groundwater-flow model encompasses nearly $180,963 \mathrm{mi}^{2}$ of the land contributing drainage to Lake Michigan and the surrounding area, which includes parts of Wisconsin, Illinois, Indiana, Ohio, Michigan, and Ontario, Canada (fig. 1). Laterally, the model grid is divided into a series of 391 rows and 261 columns of variably spaced cells. Model cells range in area from $0.9 \mathrm{mi}^{2}$ $(5,000 \mathrm{ft}$ by $5,000 \mathrm{ft})$ in the center of the model to $288 \mathrm{mi}^{2}$ $(68,930 \mathrm{ft}$ by $116,490 \mathrm{ft})$ at the external boundaries of the model. The variably spaced grid cells were established so that the refined portion in the center of the model, or near-field, (fig. 1) overlies the major pumping centers for greater modelsolution accuracy.

The model simulates groundwater flow in geologic units within the region, ranging in age from the glacial deposits of Quaternary age at the land surface to the bedrock of Precambrian age at depth. The model is vertically discretized into 20 variable-thickness layers. The top three layers of the model represent the unconsolidated glacial and alluvial deposits within the basin. The remaining 17 layers simulate the stratified bedrock units of the Wisconsin, Kankakee, Findlay, and Algonquin Arches and the Michigan Basin (Feinstein and others, in press). In total, the maximum vertical thickness of the model reaches approximately $15,000 \mathrm{ft}$. Initial aquifer properties used in the model were gathered from previous studies and a variety of databases in the region (Feinstein and others, in press; Lampe, 2009; Arihood, 2009). Groundwater-flow conditions were simulated over the time period 1864-2005. A version of the regional model that simulated all geologic units as initially unconfined was used as the base simulation for all TMR and LGR simulations developed during this study. The unconfined version of the regional model was used as the platform because it does a better job than the confined version in representing the conditions of the upper part of the aquifer system where groundwater and surface- water exchange is important.

Lastly, one of the objectives for developing the regional model was to provide a platform for development of embedded, higher-resolution models that can be used to address water-management issues at smaller (local) scales (Feinstein and others, in press). The current study is a demonstration of how the regional model may be used to that end.

\section{Model-Grid Refinement}

The location for the grid refinement investigation was chosen to illustrate a setting typical of the Great Lakes Basin and was based on three criteria: the inset model should be in the near-field portion of the regional model, it should include the glacial- and bedrock-aquifer units, and the inset area should include some headwater stream locations. The selected area was in the central part of Michigan's Lower Peninsula (fig. 1) where there is appreciable glacial material (layers 1-3) as well as a thick bedrock aquifer (sandstone of Pennsylvanian age, layer 5) (fig. 2).

\section{Refined-Model Development}

Prior to refining the grid, the regional groundwaterflow model was transferred from MODFLOW-2000 (SEAWAT-2000) to MODFLOW-2005 using Groundwater Vistas ${ }^{\circ}$. Grid refinement for the area of interest was done as a twostage process to achieve a cell size suitable for stream-aquifer interactions. This was done to balance the improvement in model accuracy in the area of interest while minimizing errors along the boundaries of the refined model. When very large refinement ratios are used, errors in the model solution at the boundaries of the refined model may increase (Mehl and Hill, 2006). To avoid that phenomenon, the refinement was done in two stages. In addition, downsizing to an intermediatescale model made the process more computationally efficient. Rather than having to solve the entire regional model in conjunction with the target local area, a smaller intermediate area made simulation times more manageable. Lastly, the regional model simulated the surface-water network using the river package. By refining to an intermediate-scale model, it became easier to simulate surface-water features using the SFR1 package in MODFLOW-2005. This was important because it allowed for the use of a beta version of MODFLOW-LGR, which enabled routing of streamflow between the coupled intermediate and local models.

An intermediate-scale model was initially extracted from the regional model using traditional TMR techniques. A second refinement was done on the intermediate-scale model to produce a local-scale model using the LGR technique. All physical properties from the calibrated regional model except recharge, land-surface elevation, and stream geometry were retained. A summary of the physical properties used in the intermediate and local models is found in tables 1 and 2, respectively. A complete description of the development and properties of the regional Lake Michigan Basin groundwaterflow model is documented in Feinstein and others (in press).

The regional model was simulated and calibrated using the codes MODFLOW-2000 (Harbaugh and others, 2000) and SEAWAT-2000 (Langevin and others, 2003). SEAWAT-2000 simulates flow of variable-density fluids, which was necessary owing to the presence of saline water and brines in some of the deeper bedrock units in the regional model. For the intermediate and local models developed during this study, the code MODFLOW-LGR (Mehl and Hill, 2006) was used for all simulations, although this code does not simulate flow of variable-density fluids. However, this was not a problem because the salinity of fluids in the bedrock simulated in the area of grid refinement is well below the 10,000 milligrams per liter $(\mathrm{mg} / \mathrm{L})$ threshold for saline water. 


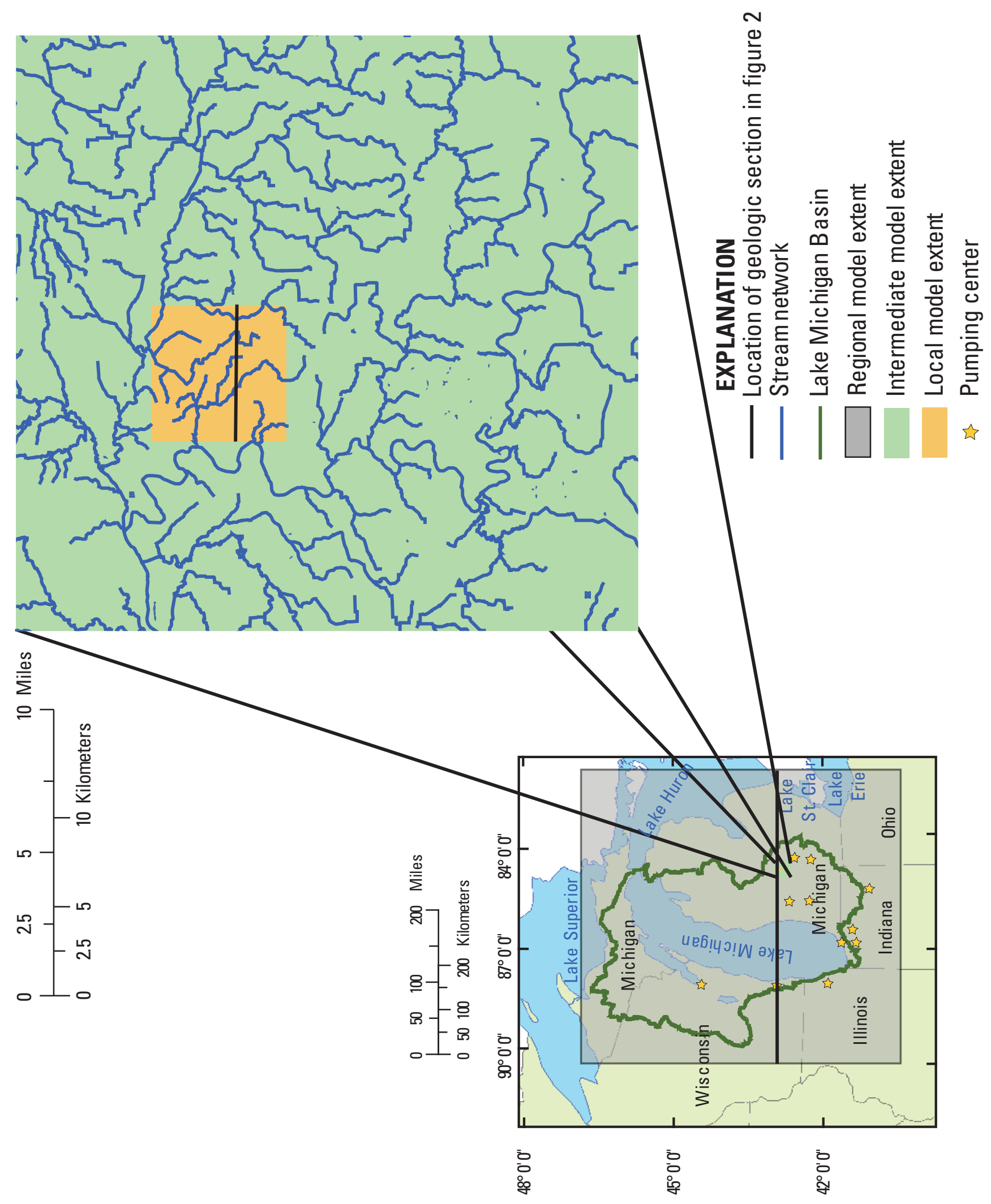

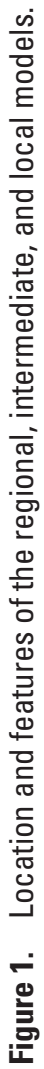



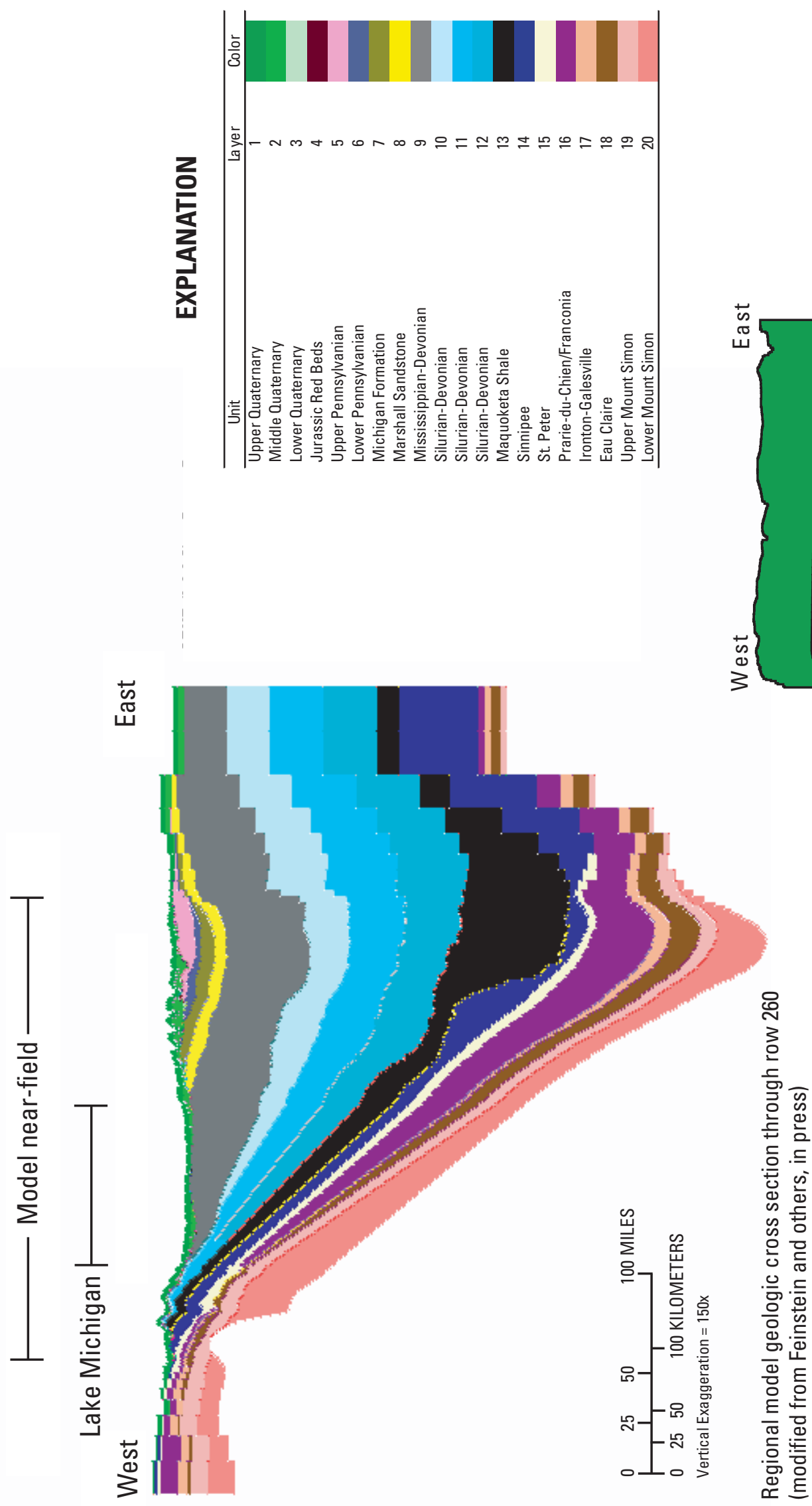
Table 1. Summary of physical properties used for the intermediate model.

[ft, feet; d, day; E, the number is multiplied by 10 to the denoted power]

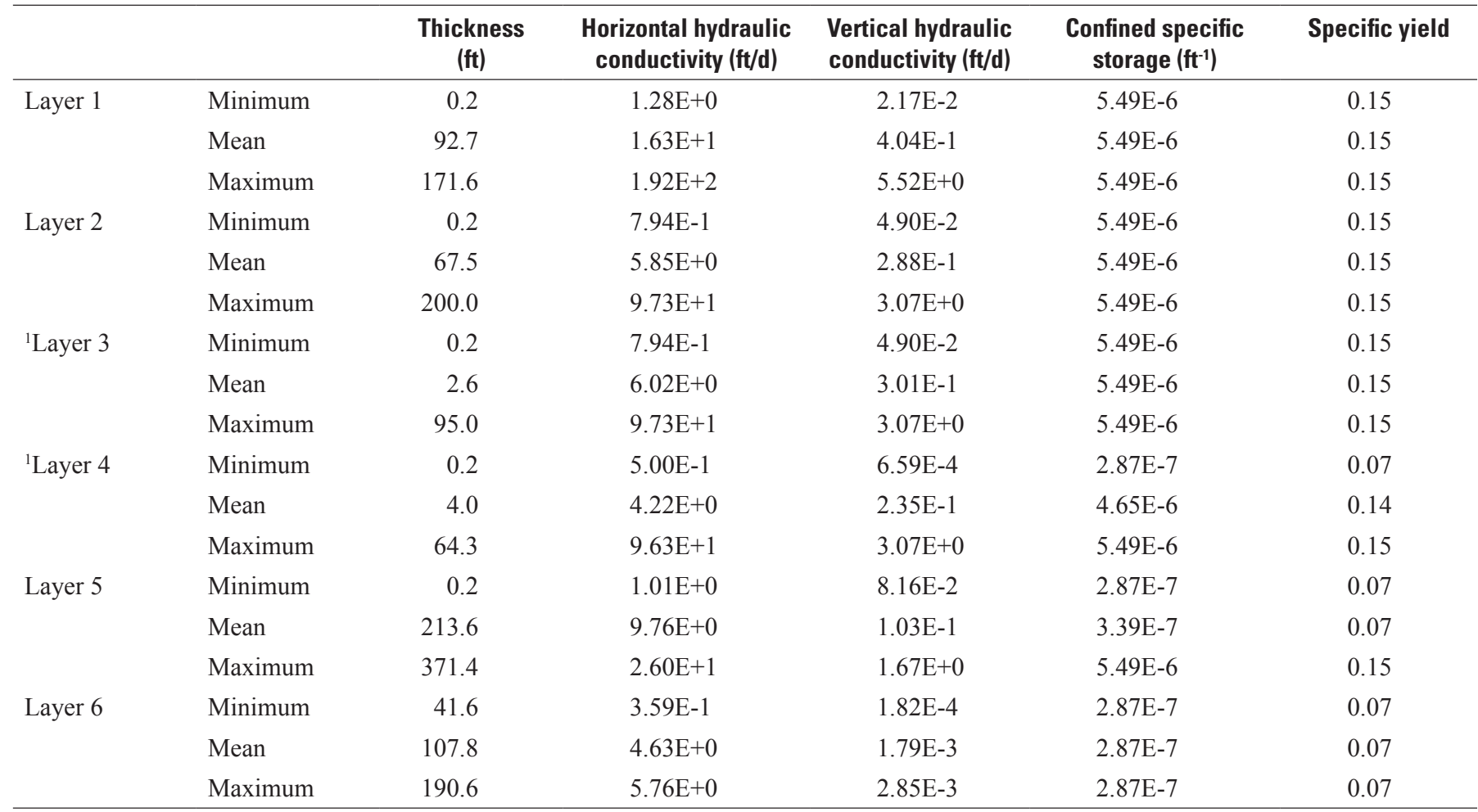

${ }^{1}$ Layers 3 and 4 are absent in areas of the model so the physical properties reflect properties of the layer above.

Table 2. Summary of physical properties used for the local model.

[ft, feet; $\mathrm{d}$, day; E, the number is multiplied by 10 to the denoted power]

\begin{tabular}{|c|c|c|c|c|c|c|}
\hline & & $\begin{array}{c}\text { Thickness } \\
(\mathrm{ft})\end{array}$ & $\begin{array}{l}\text { Horizontal hydraulic } \\
\text { conductivity (ft/d) }\end{array}$ & $\begin{array}{l}\text { Vertical hydraulic } \\
\text { conductivity (ft/d) }\end{array}$ & $\begin{array}{c}\text { Confined specific } \\
\text { storage }\left(\mathrm{ft}^{-1}\right)\end{array}$ & Specific yield \\
\hline \multirow[t]{2}{*}{ Layer 1} & Minimum & 39.0 & $3.11 \mathrm{E}+0$ & $4.78 \mathrm{E}-2$ & $5.49 \mathrm{E}-6$ & 0.15 \\
\hline & Maximum & 135.5 & $6.17 \mathrm{E}+1$ & $1.78 \mathrm{E}+0$ & $5.49 \mathrm{E}-6$ & 0.15 \\
\hline Layer 2 & Minimum & 50.2 & $1.06 \mathrm{E}+0$ & $8.57 \mathrm{E}-2$ & $5.49 \mathrm{E}-6$ & 0.15 \\
\hline \multirow[t]{3}{*}{${ }^{1}$ Layer 3} & Minimum & 0.2 & $1.06 \mathrm{E}+0$ & $8.57 \mathrm{E}-2$ & $5.49 \mathrm{E}-6$ & 0.15 \\
\hline & Mean & 7.6 & $5.16 \mathrm{E}+0$ & $4.19 \mathrm{E}-1$ & $5.49 \mathrm{E}-6$ & 0.15 \\
\hline & Maximum & 58.7 & $3.78 \mathrm{E}+1$ & $3.07 \mathrm{E}+0$ & $5.49 \mathrm{E}-6$ & 0.15 \\
\hline${ }^{1}$ Layer 4 & Minimum & 0.2 & $1.06 \mathrm{E}+0$ & $8.57 \mathrm{E}-2$ & $5.49 \mathrm{E}-6$ & 0.15 \\
\hline \multirow{2}{*}{ Layer 5} & Mean & 140.0 & $4.98 \mathrm{E}+0$ & $1.00 \mathrm{E}-1$ & $2.87 \mathrm{E}-7$ & 0.07 \\
\hline & Maximum & 234.6 & $4.98 \mathrm{E}+0$ & $1.00 \mathrm{E}-1$ & $2.87 \mathrm{E}-7$ & 0.07 \\
\hline \multirow[t]{3}{*}{ Layer 6} & Minimum & 73.3 & $4.00 \mathrm{E}+0$ & $1.21 \mathrm{E}-3$ & $2.87 \mathrm{E}-7$ & 0.07 \\
\hline & Mean & 96.9 & $5.06 \mathrm{E}+0$ & $2.10 \mathrm{E}-3$ & $2.87 \mathrm{E}-7$ & 0.07 \\
\hline & Maximum & 113.1 & $5.76 \mathrm{E}+0$ & $2.81 \mathrm{E}-3$ & $2.87 \mathrm{E}-7$ & 0.07 \\
\hline
\end{tabular}

${ }^{1}$ Layers 3 and 4 are absent in areas of the model so the physical properties reflect properties of the layer above. 


\section{Construction of Intermediate and Local Model Grids}

An initial grid-refinement routine was used to develop an intermediate-scale model from the Lake Michigan Basin regional model. To assist in modifying the files associated with MODFLOW, the graphical pre- and post-processing program,

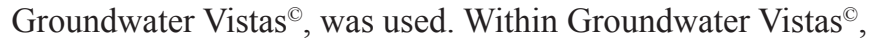
an automated TMR process is available (Rumbaugh and Rumbaugh, 2007) for extracting a refined portion of the regional model. A $453.8 \mathrm{mi}^{2}$ area was extracted from the regional model and discretized into 230 rows and 220 columns. The resulting intermediate-scale model had cell dimensions of $500 \mathrm{ft}$ per side, or $1 / 10^{\text {th }}$ the side dimensions of the cells in the regional model. Only the top six layers and properties in the regional model were translated directly to the intermediate (and local) models. All layers were simulated using the convertible layer type 3 option in the layer property flow (LPF) package (Harbaugh, 2005). However, the layer top and bottom elevations were interpolated between regional model cells so that the cell boundaries did not have sharp, blocky transitions at the locations of the original regional cell boundaries.

The elevation of the top of layer 1 of both the intermediate and local models was handled differently than the elevations of other layer surfaces. This top surface was recalculated for the refined grids by taking the average 30-m Digital Elevation Model (DEM) (U.S. Geological Survey, 2006) elevation for each cell and assigning that as the top elevation within the geospatial data-processing program, ArcMap (Environmental Systems Research Institute, Inc., 2008). This was done because the top of layer 1 elevation in the regional model used the average DEM elevation for the 5,000 ft cell, which appreciably smoothed the surface topography. The refined cell size of the intermediate model allowed for improved resolution of the land-surface features.

Only layers 1-6 were used in the simulations for the intermediate- and local-scale models because the hypothetical scenarios in these models tested only near-surface processes. Keeping the deeper layers in the regional model (layers 7-20) would make the evaluation of the head solution computationally expensive, leading to longer simulation run times. Additionally, in those deeper layers, the salinity of the groundwater at depth adds complexity to the simulation of flow for this area. There was no additional vertical refinement of the regional model layering for the intermediate- and local-scale models.

The intermediate model that was generated from the TMR of the regional model had a cell size of $500 \mathrm{ft}$ per side. Although this increased the resolution of the model, an even smaller cell size was required for investigation of groundwater/surface-water interactions. Therefore, a local-scale model with a cell size of approximately $71.43 \mathrm{ft}$ per side was generated using Groundwater Vistas ${ }^{\odot}$. The local-scale model covered an area (fig. 1) of approximately $21.7 \mathrm{mi}^{2}$ and was composed of 350 rows by 350 columns. Again, in this case, the top and bottom elevation of the layers of the model were interpolated from elevations used in the intermediate-scale model to avoid coarse transitions in cell geometry between locations of the former intermediate cell boundaries. As before, the 30-m DEM was used to assign elevation to the top of layer 1. However, in this case, a nearest-neighbor algorithm within ArcMap (Environmental Systems Research Institute, Inc., 2008) was used to assign the DEM elevation to the model cell in layer 1 . This algorithm was used because the model cell size was smaller than the DEM cell size.

The local-model cell-size of $71.43 \mathrm{ft}$ per side was chosen to be a 7-to-1 ratio from the local to intermediate model-cell dimensions. This ratio of cell dimensions was chosen so that the LGR process for MODFLOW-2005 (Harbaugh, 2005) could be used. An odd number ratio is required for a cell center to be shared correctly between the parent and child models (Mehl and Hill, 2006); in this case, the intermediate and the local model. The dimensions of the local grid were then adjusted to 344 rows by 344 columns so that only the shared centers of the local model align with the local model region of the intermediate model (fig. 3).

\section{Boundary Conditions of the Refined Grids}

A specified-head-boundary condition was used on the external cells of the intermediate model. A no-flow boundary was used at the bottom of the model. This boundary was selected at the base of layer 6 because layers 6 and 7 serve as confining units in the regional model. Likewise, the groundwater begins to get saline below layer 6 . Because of the density difference in the water, as well as the low hydraulic conductivity of layers 6 and 7, very little flow was expected upward into layer 6 . The values assigned to each boundary cell were taken from the head solution of the calibrated regional model. Specifically, the head solution used was from the final stress period of the regional model, representing the period 2001-05. For the TMR process, a linear interpolation of the regional model heads was used in assigning the specified-head boundary to the intermediate model cells along the outer boundary. This was done to avoid a head distribution with sharp contrasts along the cell boundaries that overlie the previous regional model cell boundaries.

\section{Recharge}

Recharge estimates used for the intermediate- and localscale models were derived from a modified ThornthwaiteMather soil water balance (SWB) code (Westenbroek and others, 2010). The SWB code estimates recharge for an area using precipitation, temperature, land-use classification, hydrologic soil type, land-surface slope, and soil-water capacity data. The initial estimates of these inputs were used to generate an estimate of recharge used in the regional flow model (Feinstein and others, in press). The recharge estimates developed from the SWB code were compared to recharge estimates developed from base-flow analysis of gaged watersheds within the 


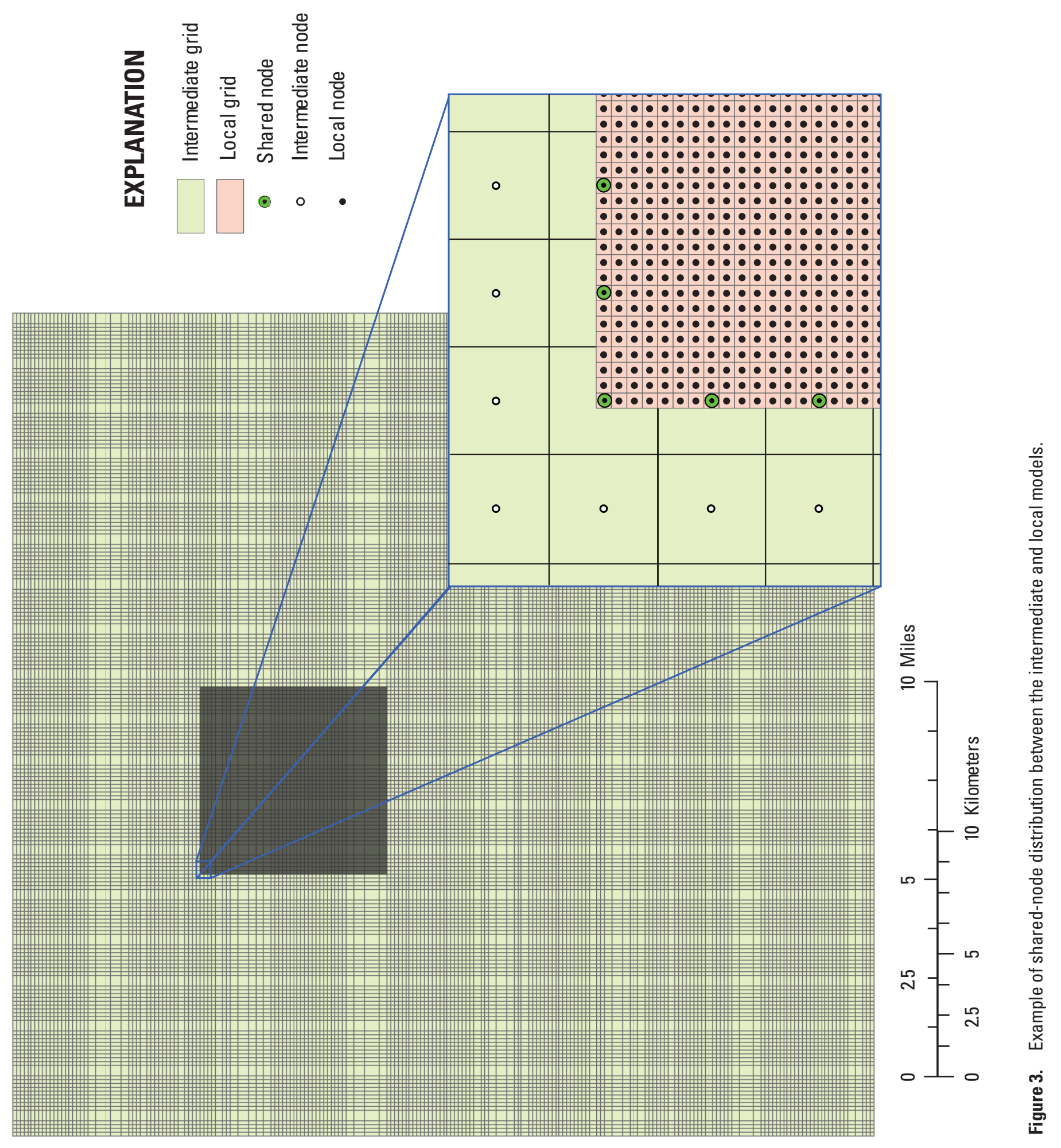


regional study area. For the regional model, the SWB inputs were then adjusted to produce a recharge result that better matched the base-flow-derived recharge estimates. With the exception of temperature and precipitation, input parameters to the SWB code for the intermediate and local models were identical to those used in calculating recharge for the regional model. Temperature and precipitation data sets for the intermediate- and local-scale models were obtained from an atmosphere-ocean coupled general circulation model (AOGCM) (Hayhoe and others, 2008; Maurer and others, 2002).

The AOGCM used provided potential temperature and precipitation realizations on a daily basis for the period 19602099. The data output from the AOGCM reflects potential conditions assuming a high, global greenhouse-gas-emission scenario (A1fi scenario) (Hayhoe and others, 2008). Using the climatic data derived from the AOGCM as the input to the SWB model provided a means to estimate future recharge and the effects that global climate change may have on recharge. Likewise, the effect of potential climate change on a groundwater system can be examined by using the estimated recharge for simulations on the local and intermediate models. To that end, one of many possible long-term climate scenarios was developed using AOGCM-derived recharge estimates from the period 1991-2044. Thus, climate-change results should be viewed as illustrative of the approach taken and what could happen in a temperate watershed, but should not be considered a definitive forecast.

The recharge results obtained by using the AOGCM input to the SWB model were interpolated to both the intermediate- and local-model scales using a b-spline method (Stephen M. Westenbroek, U.S. Geological Survey, personal commun., 2009). A series of monthly recharge realizations were developed from the SWB model for the period 1991-2044. The recharge results were output as a series of grids that reflected the estimated recharge for a given month. These monthly recharge grids then were combined and translated into a MODFLOW-2005 recharge package (Harbaugh, 2005). The initial calculation of recharge estimates, based on the AOGCM, was appreciably lower than current-condition average recharge used in the calibrated regional model for the interval over which the two sets of estimates overlap. For the time period 1991-2005, the AOGCM-derived recharge estimates for the local model averaged $4.82 \mathrm{in} / \mathrm{yr}$. Recharge values estimated in the calibrated regional model over the same period for the local model area averaged $7.81 \mathrm{in} / \mathrm{yr}$. To maintain continuity between the regional, intermediate, and local models, recharge estimates derived from the AOGCM model for the entire period (1991-2044) were scaled up by a factor of 1.622. This adjustment raised recharge estimates derived from the AOGCM inputs to an average of $7.81 \mathrm{in} / \mathrm{yr}$ over the local model area. Although this adjustment changes the magnitude of the recharge, it did not affect the seasonal distribution of the recharge given by the AOGCM model (fig. 4).

\section{Surface-Water Network}

Refinement of the regional model allowed for a more accurate representation of the surface-water network in the intermediate and local models. A comparison of the same surface-water network over a common area among the three scales of models (fig. 5) illustrates the effect of cell size on the surface-water representation. For the local-model area, roughly 64 percent of the cells in the regional model include surface-water features; in the intermediate model, approximately 14 percent of the cells include surface-water features; and for the local model, 2.3 percent of the cells include surface-water features. For these reasons, it was necessary to reexamine the surface-water network developed for the regional model and adapt it for use with the refined model grids.

There are many surface-water features within the intermediate- and local-model areas. The intermediate model includes surface-water features from four different 8-digit hydrologic unit codes (HUCs) that drain into Lake Michigan (fig. 6). (Surface-water drainage generally is to the west toward Lake Michigan.) There are approximately 170 streams and 48 surface-water bodies (lakes and wetlands) within the intermediate-model area; there are 16 streams but no other surface-water bodies within the local-model area.

The source of the surface-water features used for the refined models was the 1:100,000 NHDPlus dataset (Horizon Systems Corporation, 2006). The NHDPlus dataset is a series of geospatial datasets built on the framework of the National Hydrography Dataset (NHD). Results of this compilation and analysis yielded many useful products, some of which include an improved 1:100,000 NHD; a set of value-added attributes to enhance stream-network navigation and analysis, flow direction, flow accumulation, and elevation grids; and flow line min/max elevations and slopes (Horizon Systems Corporation, 2006). These enhancements to the NHD (provided by the NHDPlus effort) provided a routed-streamflow network, water-feature elevations, and water-feature geometries, which were needed to develop the model stress packages that simulate surface-water features in the intermediate- and local-scale models.

Simulation of surface-water features other than streams (i.e., lakes and wetlands) within the intermediate model (none are present in the local model) was done using the generalhead boundary (GHB) package (Harbaugh, 2005). Required data to simulate the surface-water features other than streams within the intermediate-model area were extracted from the NHDPlus dataset within ArcMap (Environmental Systems Research Institute, Inc., 2008). The stages for the individual water features were based on the average DEM elevation within the water body. A hydraulic-conductivity value of $0.015 \mathrm{ft} / \mathrm{d}$ was assigned to the bed material of surface-water bodies other than streams based on values from the literature (Calver, 2001). An arbitrary bed thickness of $0.5 \mathrm{ft}$ was used for all water bodies. This information was exported to a text file and edited in a text editor to create the GHB package. 
NON-ADJUSTED

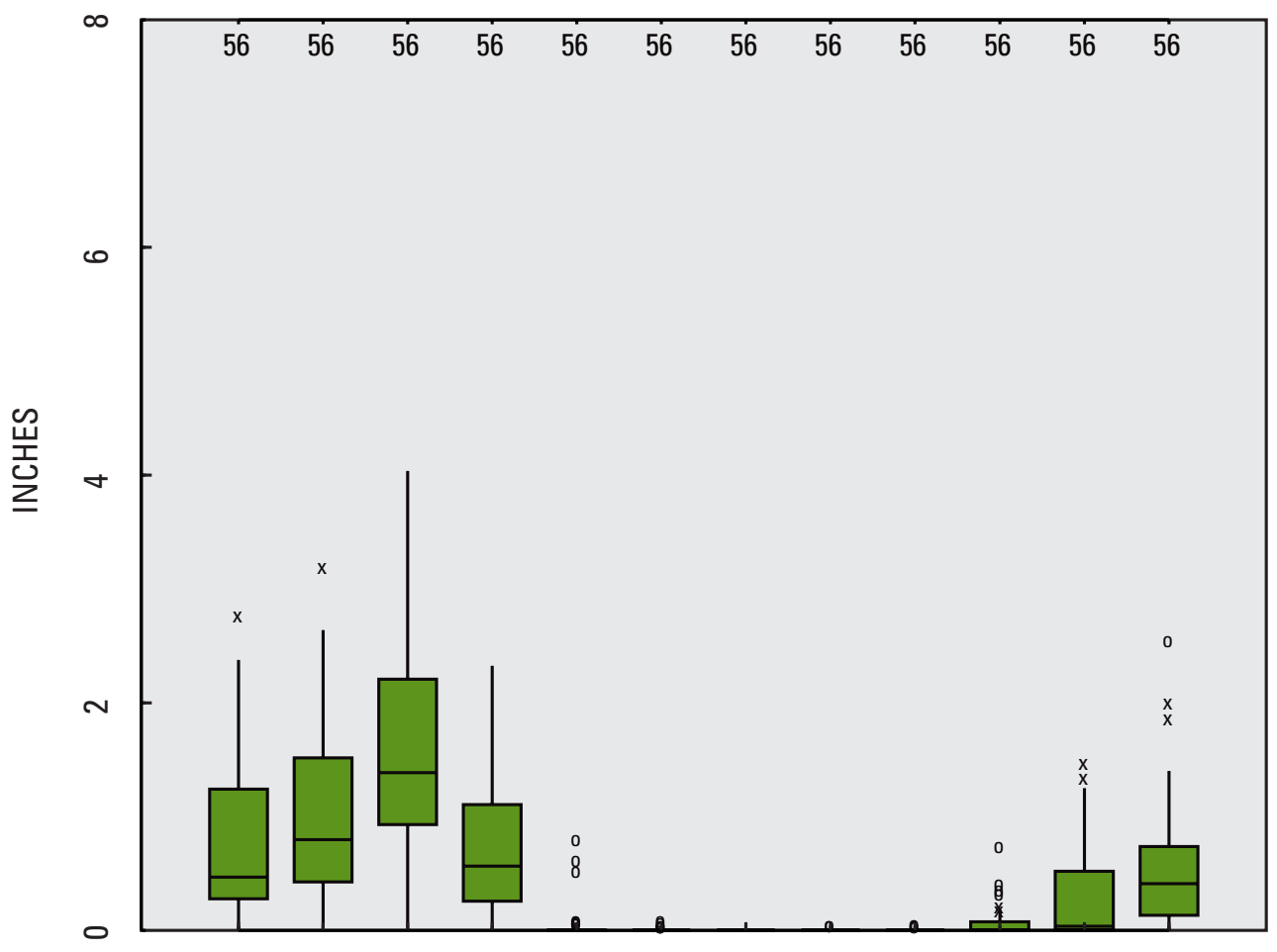

ADJUSTED

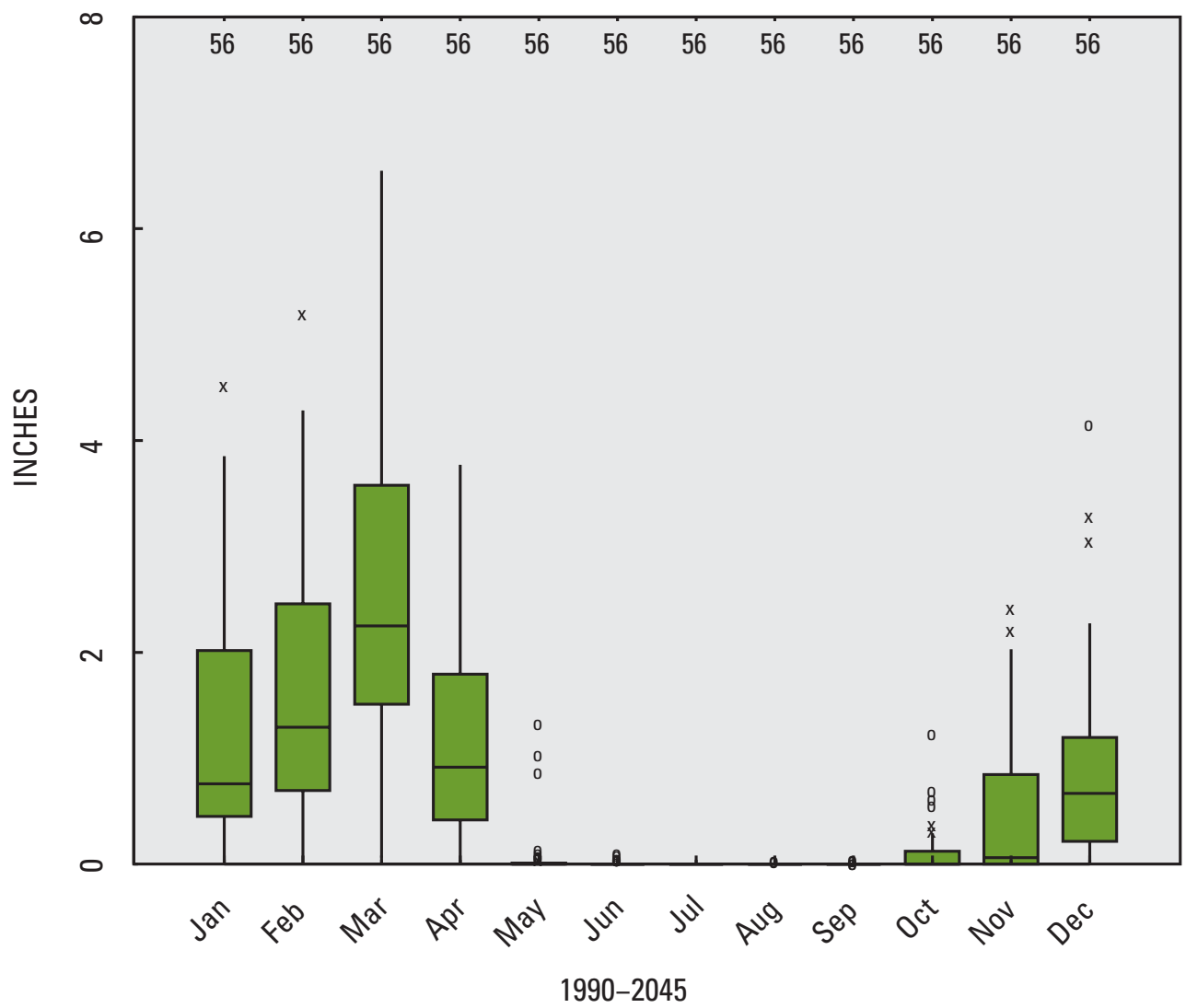

\section{EXPLANATION}

56 Number of samples

Outlier data value

0 greater than 3 times the interquartile range

Data value between

X 1.5 and 3 times the interquartile range

Data value between 1.5 times the interquartile range and the last quartile

75th percentile

median

25th percentile

Figure 4. Seasonal distribution of recharge for the adjusted and non-adjusted recharge values. 
Regional model

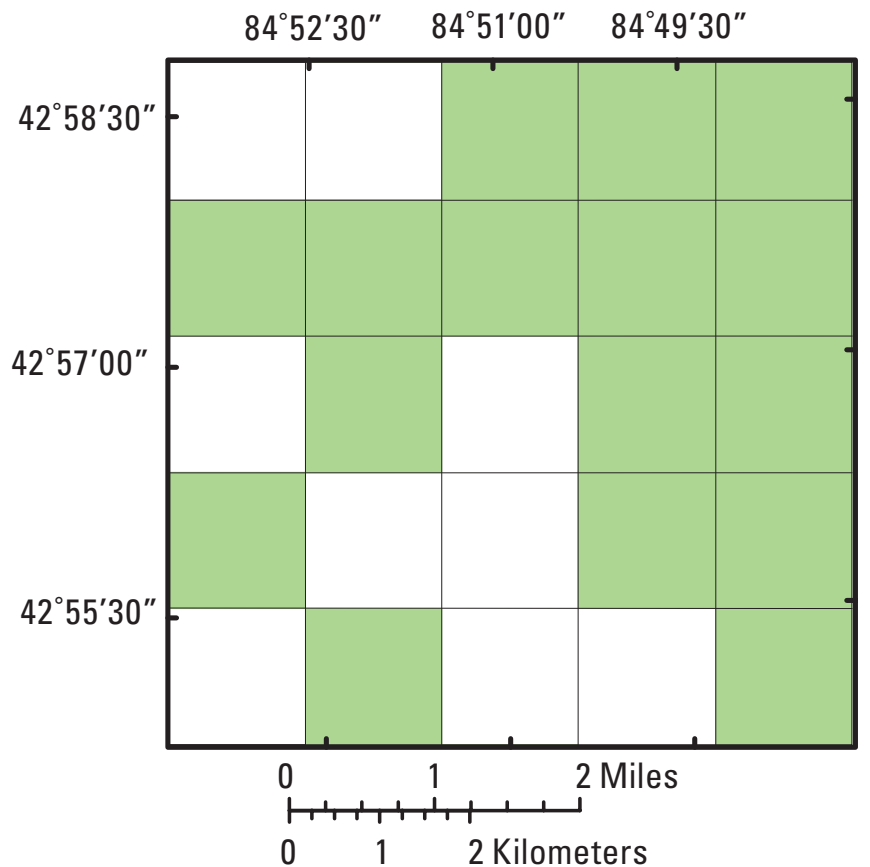

Intermediate model

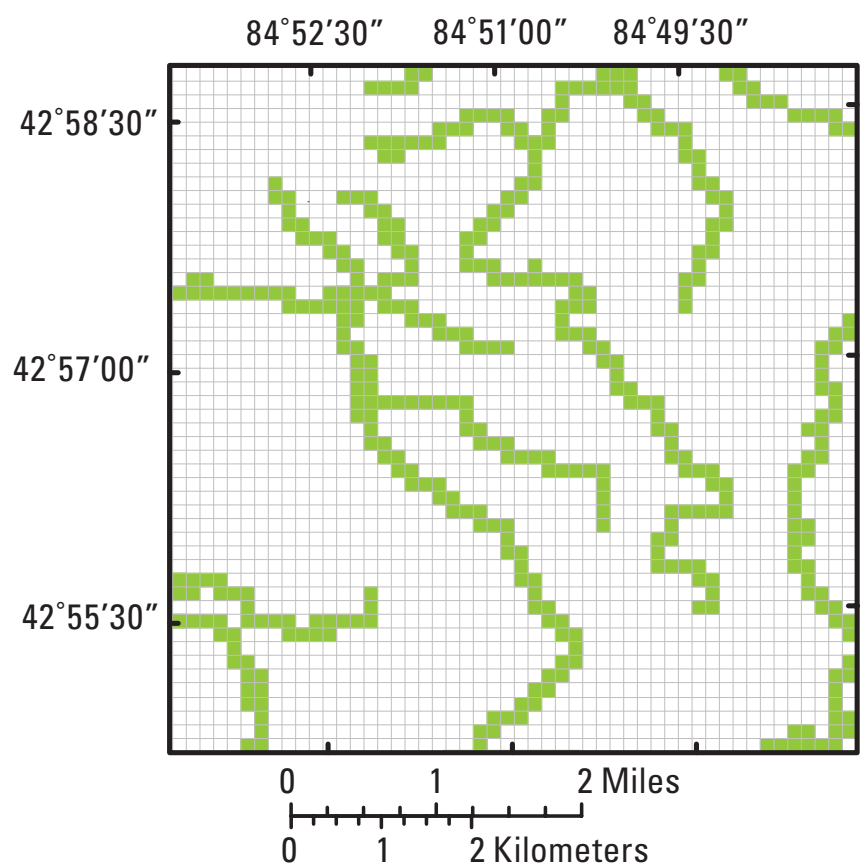

Local model

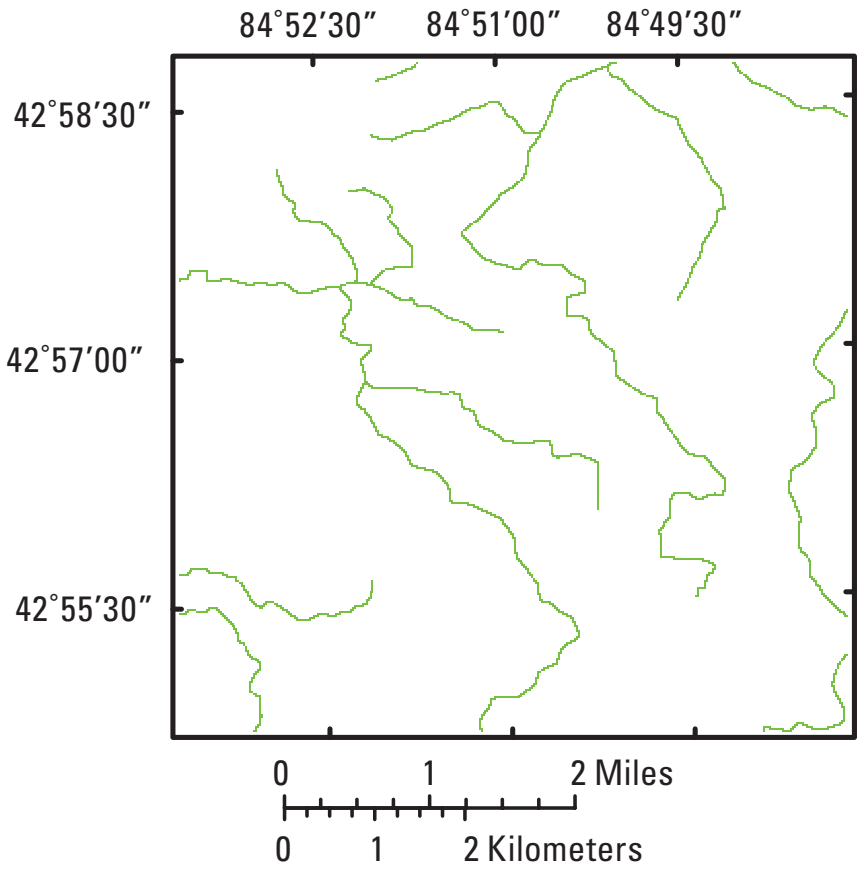

Figure 5. Surface-water network for the area of the local model shown in comparison to how it was discretized at the levels of grid refinement used in the regional and intermediate models. 

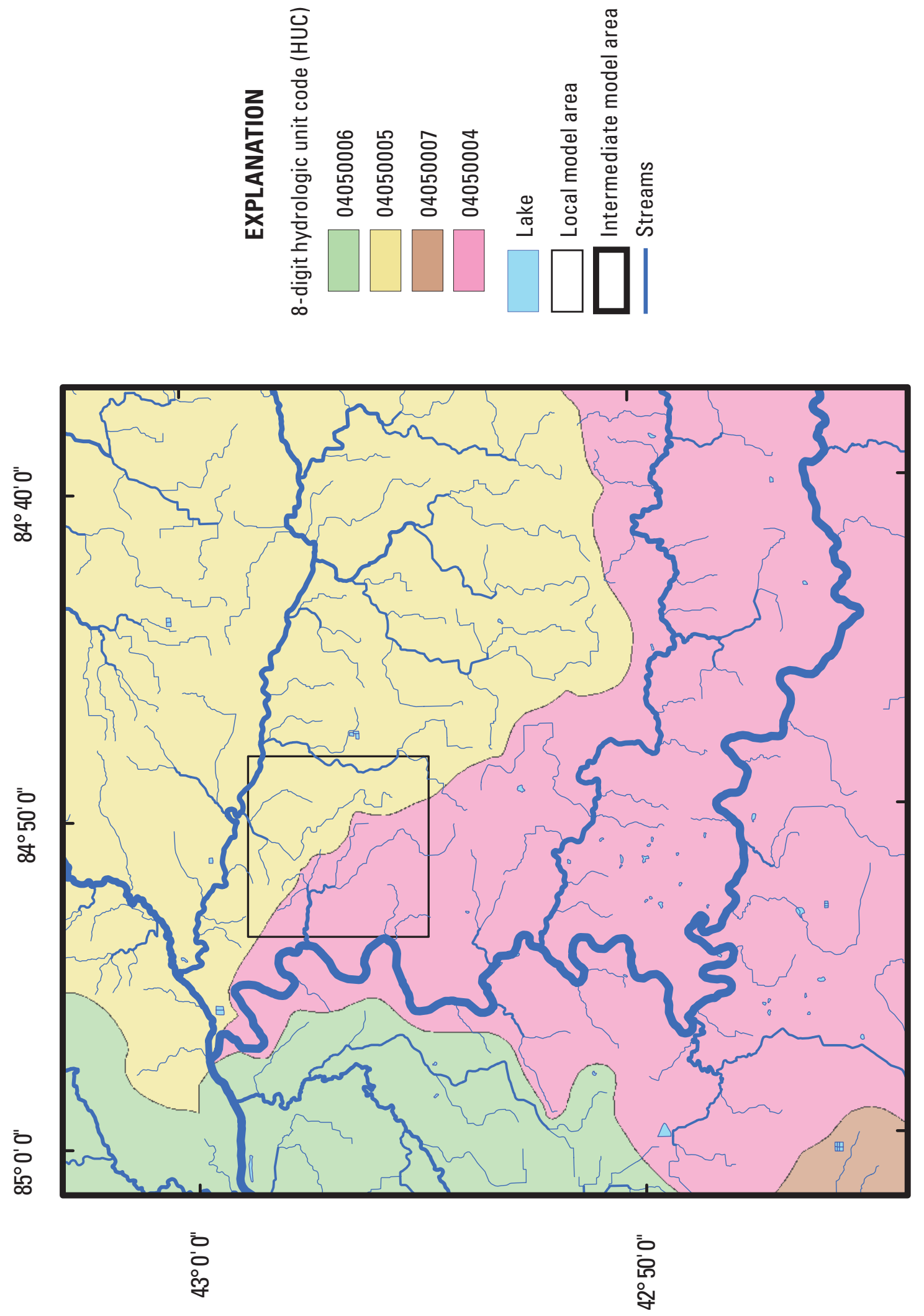

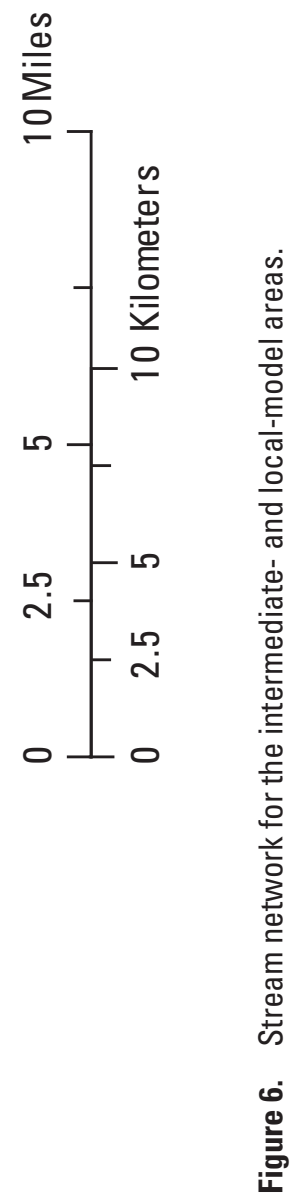


Simulation of streams within the intermediate and local models was done using the SFR1 package (Prudic and others, 2004). This package was chosen because it provides a more detailed account of surface-water/groundwater interactions than the river package (Harbaugh, 2005). The SFR1 package limits water lost from a stream to that which is carried by the stream, rather than using a set stream stage to estimate water lost from a losing reach, and the inputs needed to generate the package generally were available within the NHDPlus dataset. These required inputs included an ordered stream network, location, stream elevation, streambed thickness, streambed hydraulic conductivity, and stream geometry. After these inputs were compiled, a program add-on for ArcMap (Steven Predmore, ESRI, personal commun., 2009) was used to process the inputs and generate a formatted SFR1 file. A hydraulic-conductivity value of $0.283 \mathrm{ft} / \mathrm{d}$ was assigned to the bed material based on values from the literature (Calver, 2001). As above, an arbitrary bed thickness of $0.5 \mathrm{ft}$ was used for all streams. Further detail on the construction of the stream network used for the beta version of MODFLOW-LGR is described in appendix 1 .

\section{Refined-Model Scenarios}

Five model scenarios were developed to demonstrate the utility of grid refinement on modeling the effect of groundwater withdrawals and climate change on streamflow for the regional LMB model. All scenarios were hypothetical and built on the hydrogeologic framework of the calibrated regional model. There were no attempts to calibrate or execute parameter estimation on any of the following scenarios.

\section{Streamflow Depletion}

A series of scenarios was developed to demonstrate the effect of groundwater withdrawals on a headwater stream. Conceptually, this was done by placing a well near a headwater stream and evaluating the effect of pumping on flow in the stream (fig. 7). All scenarios were transient simulations using monthly stress periods with five time steps per stress period. Current (2010) condition simulations were run for 9 years (1991-99); these simulations used a 4-year run-up (steadystate) period to allow conditions to equilibrate. Each scenario used the modified recharge estimates developed from the SWB code discussed previously.

To achieve steady-state conditions prior to the transient simulation, the model was simulated for 3 years (36 stress periods) using constant recharge rates applicable to January 1990. Because the model had not fully equilibrated after the 3-year run-up, the model run-up period was extended to include 1990, and the evaluation of model results was done only for the period 1991-99.

In addition, a monthly flow value had to be estimated for each stream that originated outside the intermediate-model area. For those streams, the precipitation data used for the SWB (Westenbroek and others, 2010) code to calculate recharge was used as the input to the AFINCH (Holtschlag, 2009) code to derive the appropriate monthly streamflow for that segment.

Four scenarios were developed to demonstrate aquiferstream interaction and response to different screen depths of the pumped well near the stream gage (fig. 7). The first scenario was a control case with no pumping simulated near the stream. The second scenario simulated a well that was screened in the glacial deposits of layer 1 at approximately $95 \mathrm{ft}$ below ground surface. The third scenario simulated a pumping well that was screened in the deeper glacial deposits of layer 2, approximately $280 \mathrm{ft}$ below land surface. The fourth scenario placed the pumping well open to the Pennsylvanian sandstone of layer 5 at approximately $405 \mathrm{ft}$ below land surface. In each pumping scenario, the well was assigned a discharge rate of $71.4 \mathrm{gal} / \mathrm{min}$ and was located approximately $460 \mathrm{ft}$ east of the stream (fig. 7). Pumping was initiated in the first stress period and remained constant throughout the simulation.

To demonstrate the effects of pumping on streamflow, the Gage package (Prudic and others, 2004) was used to record the streamflow at a point near the well (fig. 8). The streamflow for the non-pumping control case was treated as an unstressed base case. Streamflows from the three other scenarios were compared to the streamflow from the non-pumping case. The hydrograph in figure 8 indicates that the stress on the stream is greater in the low-flow months during the late summer, fall and winter seasons owing to a combination of low recharge and continued pumping from the nearby well. During those periods, streamflow was depleted up to 100 percent, causing the stream to dry up. It should be noted that in some dry years the stream dried up in the control case, which was not affected by pumping, so during some periods there was no streamflow available for depletion.

In all cases, pumping had the effect of decreasing streamflow in the test stream, which is expected from conservation of mass (fig. 8). Although the amount of depletion among the various scenarios was similar, pumping from layer 1 had the largest effect on streamflow in the test stream. Pumping from layer 2 and pumping from layer 5 had slightly less effect on the streamflow than pumping from layer 1 because the wells in these scenarios were placed in deeper layers farther from the stream. Table 3 provides a summary of the cumulative water budget for pumping from layer 1 . This table illustrates the relative magnitude of the various components of the water budget in the test watershed. To better discern the effect of relocating the pumping well to deeper parts of the flow system, a mass-balance approach was used to determine the source of the water to the pumping well. This was done by compiling the water-budget information for the test watershed for all four scenarios. The sources of water to the pumping well were then derived by subtracting the water budget for the pumping scenario from the water budget of the naturalconditions scenario. Recharge was the same for all scenarios, 

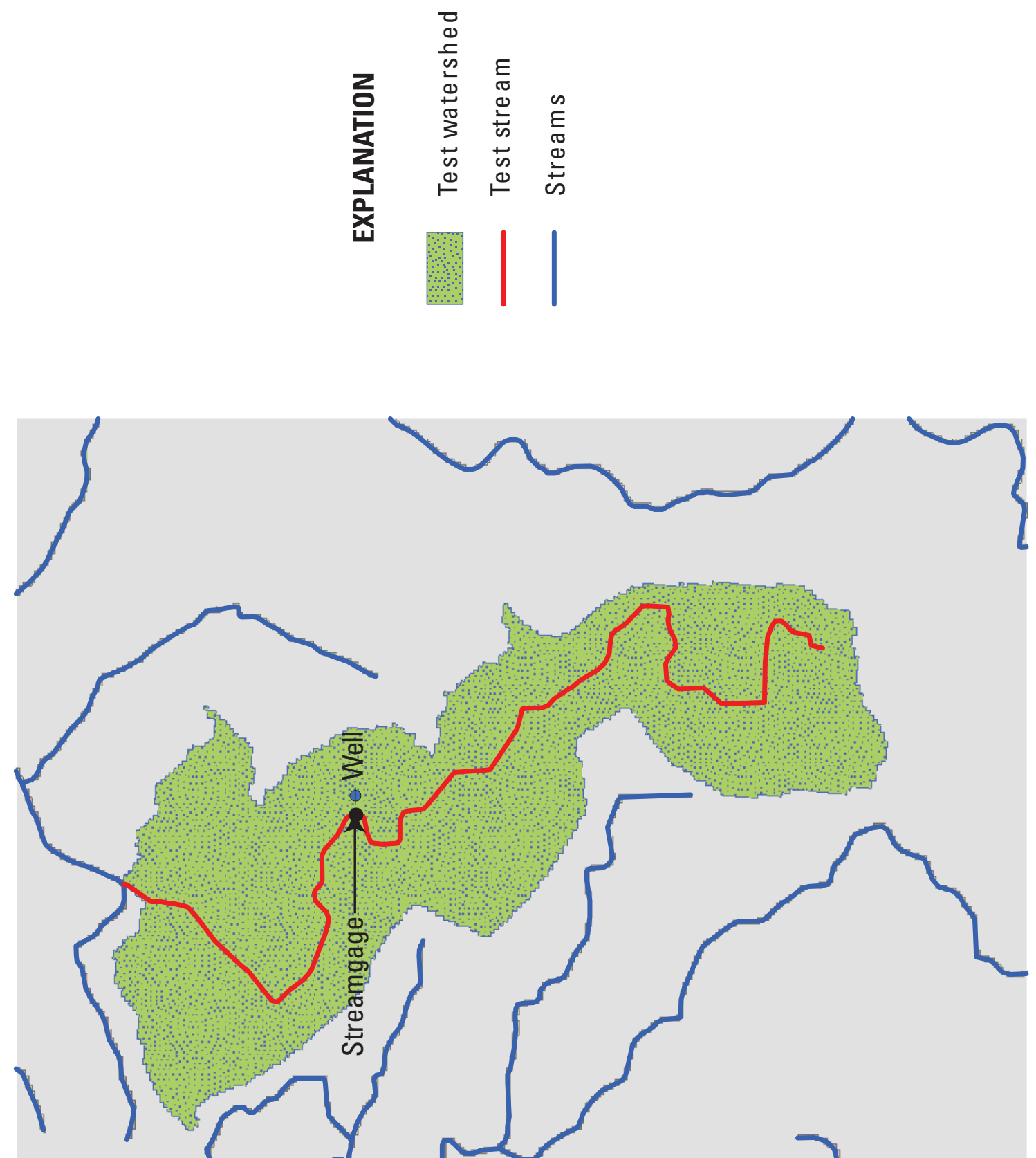

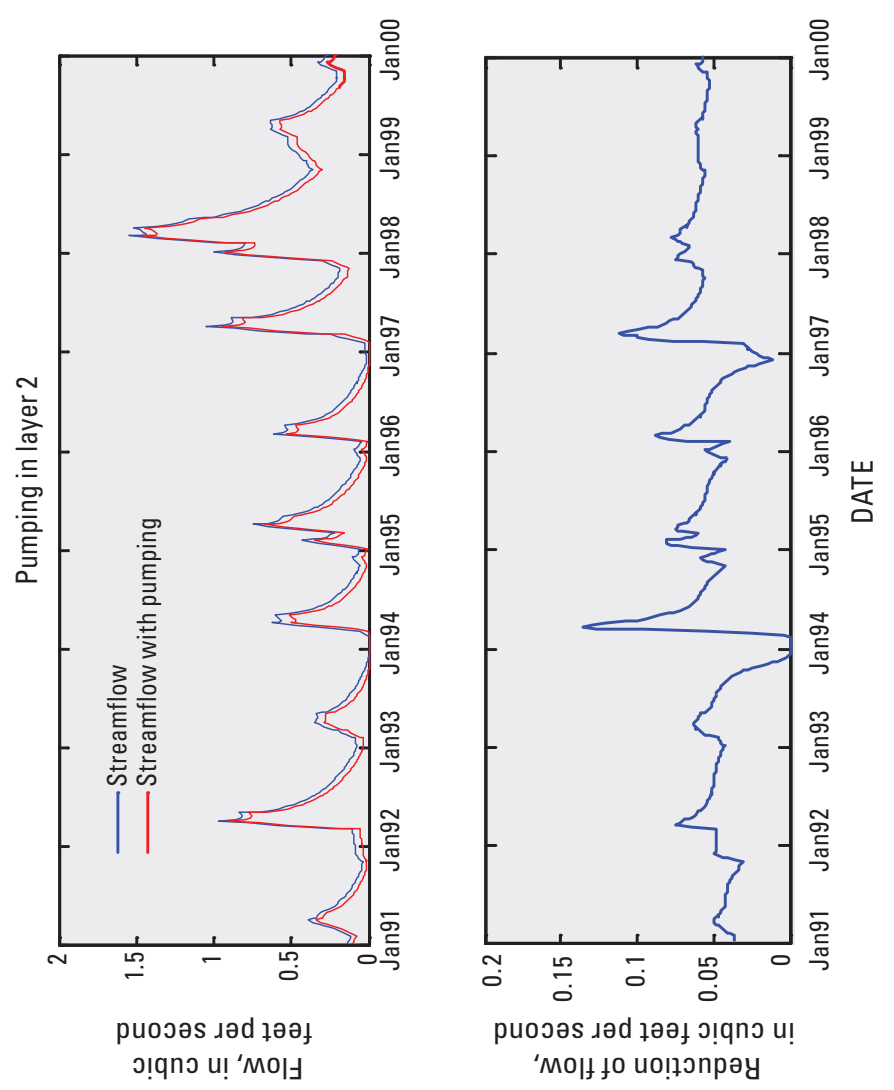

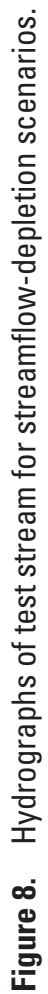
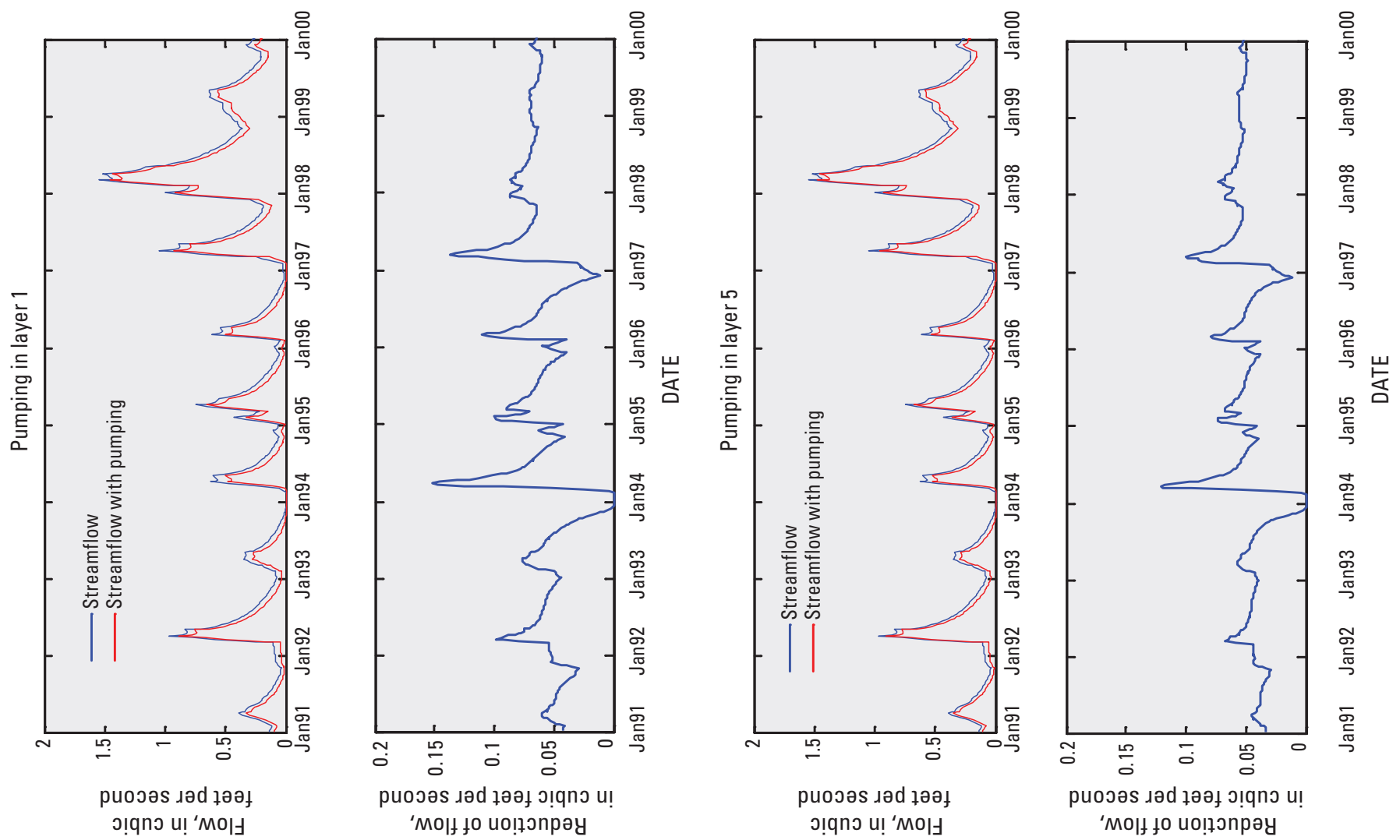
Table 3. Summary of the overall water budget in the test watershed with a well pumping in layer 1 .

[gal/min, gallons per minute]

\begin{tabular}{lrlr}
\hline \multicolumn{2}{c}{$\begin{array}{c}\text { Flux into the test watershed } \\
\text { (gal/min) }\end{array}$} & \multicolumn{2}{c}{$\begin{array}{c}\text { Flux out of the test watershed } \\
\text { (gal/min) }\end{array}$} \\
\hline \multicolumn{1}{c}{ Component } & Amount & \multicolumn{1}{c}{ Component } & Amount \\
Recharge & 108,253 & Boundary of watershed & 74,711 \\
Stream & 3,650 & Stream & 27,740 \\
Storage & 57,698 & Well & 7,710 \\
& & Storage & 59,441 \\
\hline
\end{tabular}

so that term cancelled out in the analysis. The water-budget components of interest became streamflow, storage, and lateral flow (water derived from outside the test watershed). Results of this analysis are illustrated in figure 9.

In all scenarios, the source of water to the well varied annually. During dry years, such as 1993, more water pumped from the well was derived from lateral groundwater flow and not from the stream and storage (fig. 9) because there was not as much water available in the stream (fig. 8). During a wet year, like 1997, much of the water entering the well was coming from the stream. The annual variation in sources of water to the well was similar in all cases, yet there were small differences in the magnitude of the various sources depending on the layer in which the well was located. For instance, in 1997 the well pumping from layer 1 captured $62 \mathrm{gal} / \mathrm{min}$ from streamflow, the well pumping from layer 2 captured 55 $\mathrm{gal} / \mathrm{min}$ from streamflow, and the well pumping from layer 5 captured $52 \mathrm{gal} / \mathrm{min}$ from streamflow. These results indicate that deepening the well changes the distribution of the sources of water to the well.

The effect of deepening the well was more apparent when comparing the net source of water to the well for the entire period (1991-99) (fig. 9). In all cases, the majority of the water to the well came from streamflow. As the pumping well was placed into deeper geologic units, the effect on streamflow was reduced, largely owing to the increased contribution of lateral flow of water from induced recharge from surrounding watersheds. This finding implies that for this hydrogeologic setting, to lessen the effect of pumping on a stream, a well can be placed in a deeper geologic unit, causing the well to capture the lateral flow and, perhaps, to spread its effect to other streams and (or) other watersheds.

\section{Climate-Change Scenario}

The last scenario developed for the refined models was a scenario examining the effects of potential climate change on streamflow (scenario 5). Similar to the streamflow-depletion scenarios, the climate-change scenario was a transient simulation that used a monthly stress period with five time steps in each stress period. This scenario simulated a period of 54 years (1991-2044), again with a 4-year run-up (steadystate) period to allow the model to equilibrate.

The Gage package (Prudic and others, 2004) was used to monitor streamflow at the same location as in the streamflowdepletion scenarios (fig. 7). In this scenario, climate change was simulated by variable areal recharge. The annual distribution of recharge for the simulated period is illustrated in figure 10. SWB-derived recharge was quite variable over the period simulated, ranging from $17.62 \mathrm{in} / \mathrm{yr}$ in 2011 to $3.38 \mathrm{in} / \mathrm{yr}$ in 2042. There was a slight increase in recharge until 2017 and then it generally decreased until the end of the simulation in 2044 (illustrated by the LOESS-smoothed curve in figure 10). This variation in recharge was reflected in streamflow during the simulation; however, this is only one realization of possible climate and should be considered illustrative of the type of system response that could potentially occur with climate change.

Simulated streamflow was greater during periods of high recharge and less during periods of low recharge (fig. 10). The period 2013-2022 had the greatest streamflows, which correlated to a period of higher recharge (fig. 10). The period 2035-2044 generally had the lowest recharge values, and that was reflected in low streamflows for that period (fig. 10). During this lower recharge period, the median flow for several months was zero, indicating that this stream was frequently dry.

Generally, the monthly distribution of streamflow was similar for all periods, with the highest flows during March and April and the lowest flows during October-December. However, the recharge distribution by month is slightly different (fig. 4). The highest recharge occurred during December-April, with little to no recharge taking place from May to September. In contrast, the lowest streamflows (fig.10) were observed during October-December, which indicates a lag time between the recharge decline and the ensuing decline in streamflow. 

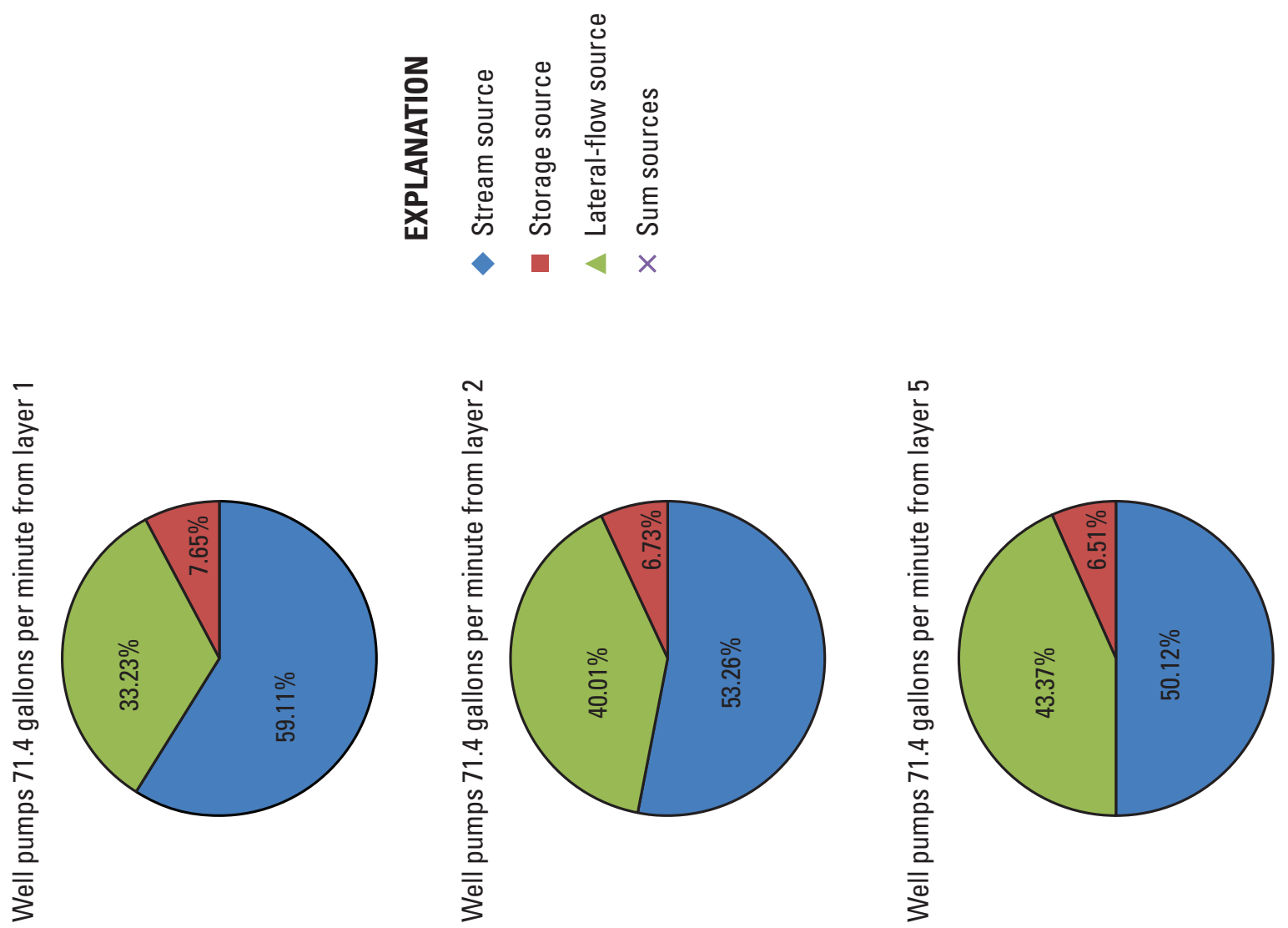

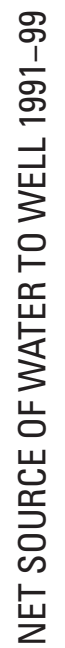

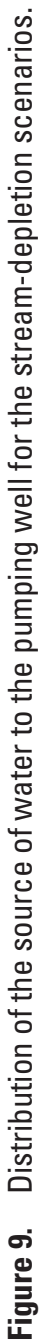
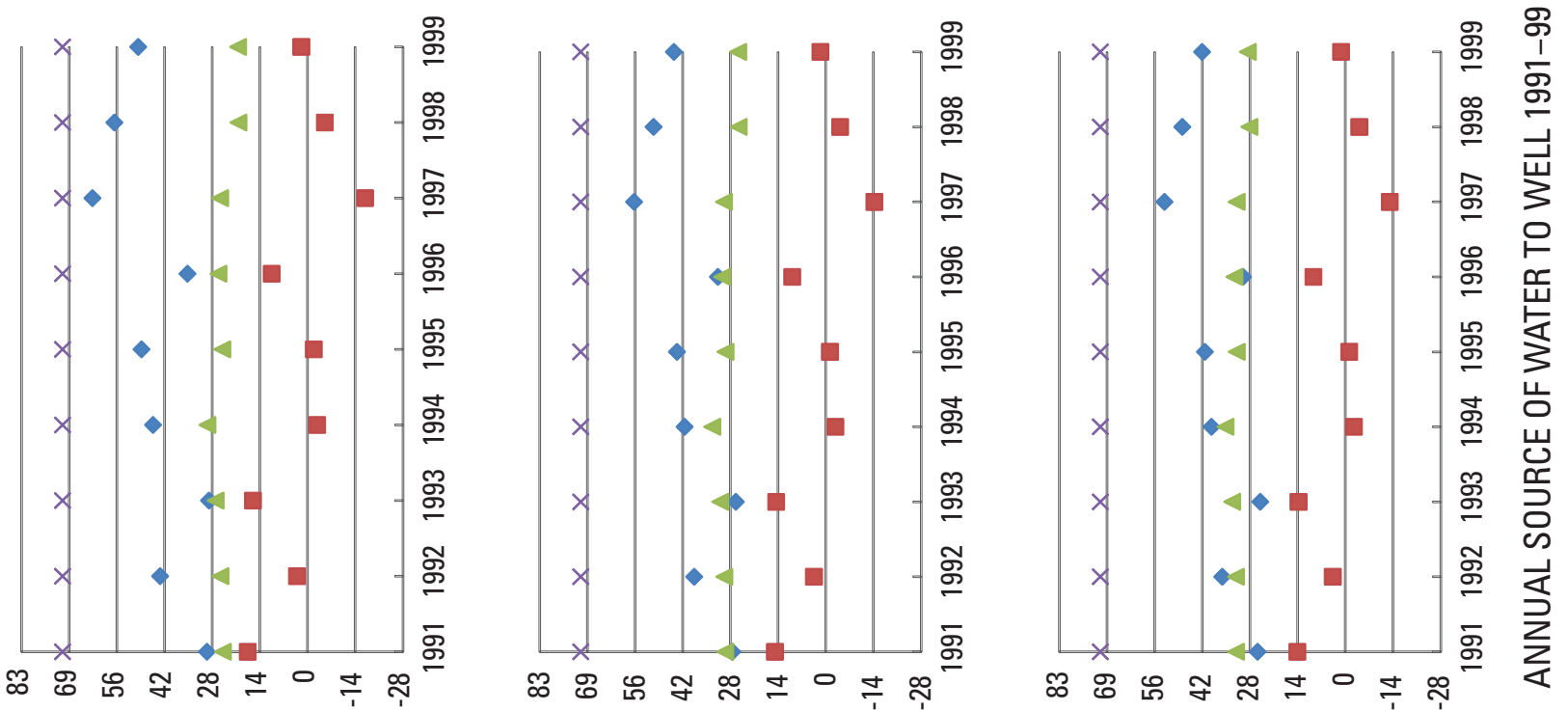

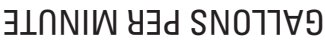



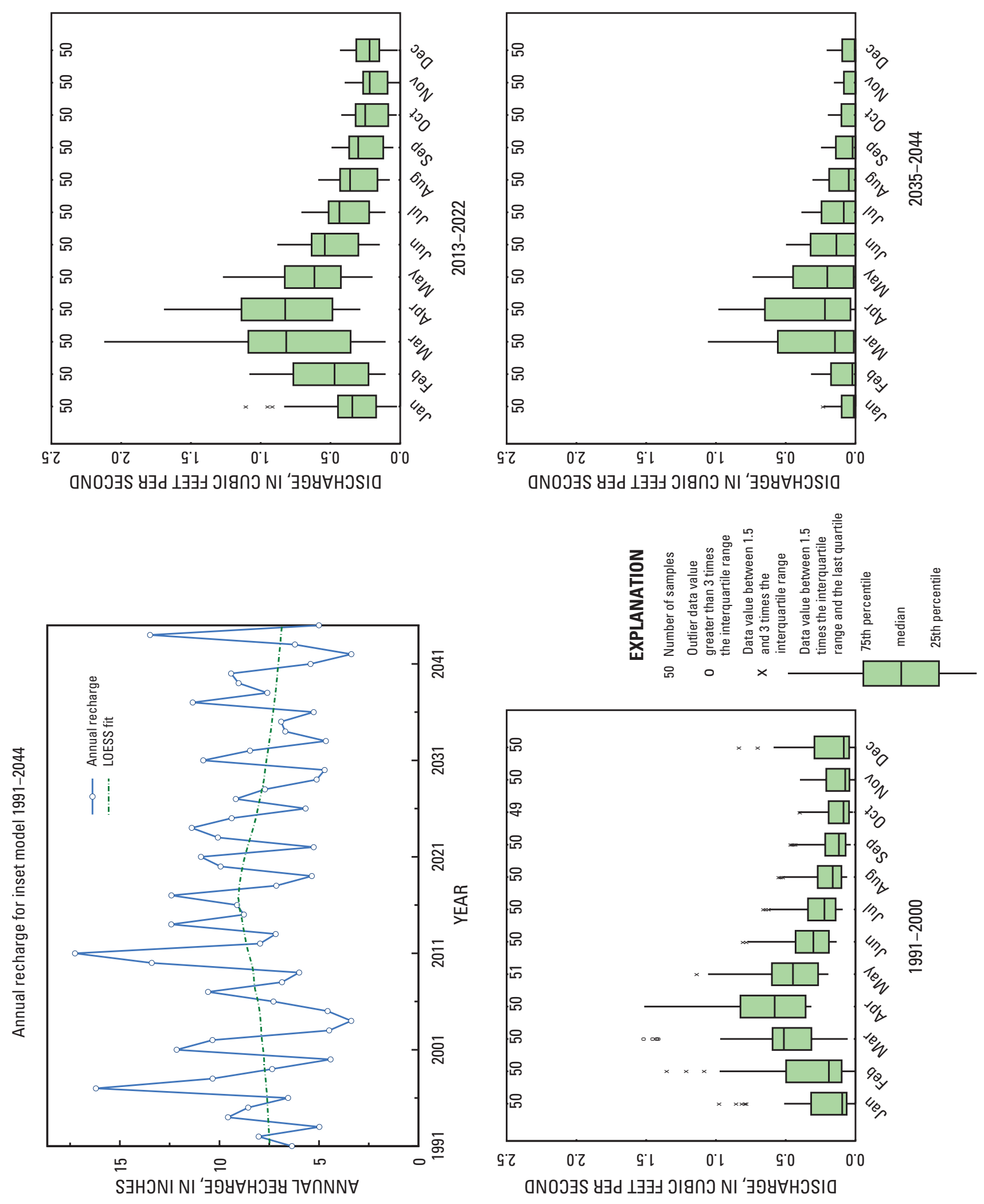


\section{Assumptions and Limitations of the Models}

There were several assumptions made for the purposes of this investigation. For instance, it was assumed that the streambed for all streams in the model area had constant thickness and constant hydraulic conductivity. This was done to facilitate the demonstration of the modeling methods used, but these characteristics could be refined using parameter estimation and field verification for actual case studies. It also was assumed that all recharge estimated using the SWB code for a dedicated stress period immediately infiltrated the water table (no unsaturated-zone flow or processes were simulated).

The assumption that the bottom of layer 6 acts as a no-flow boundary may not be adequate for simulations that take place over very long time intervals (hundreds to thousands of years). There is a low potential for flow through the bottom of layer 6, but over long time periods, the volume of flow into that layer may be appreciable. Likewise, the salinity conditions that also minimize vertical flow into and out of layer 6 may change over long periods of time. Therefore, using a no-flow boundary at the base of layer 6 may have to be reevaluated for simulations of very long time periods. Another assumption used in the model development was that the specified-head boundaries in the intermediate model were adequately representative of the current conditions and static during the model simulations. Although this may be more accurate during the 9-year stream-depletion scenarios, it poses a problem for the long-term climate scenarios. Similarly, the specified- head boundaries used in the intermediate model have the potential to affect heads and flows near the pumping well in the local model. However, the low pumping rate of the well in conjunction with the large distance $(6.4 \mathrm{mi})$ of the well from the boundaries makes this unlikely but it was not tested in these scenario models. Additionally, for the stream depletion scenarios, the gage location used for recording streamflow hydrographs does not reflect the holistic effect of the pumping well on the stream reach. However, the output from the gage used for these scenarios does illustrate the effect of a well pumping near a stream.

One limitation of the refined models in this study was that there was no vertical refinement of any of the model layers. However, future studies that may require a finer vertical discretization, such as for simulated particle tracking, could utilize this feature of LGR. The SWB results used in the intermediate and local models did not take into account the effect of stomatal resistance of plants and the variation in stomatal resistance, which may affect evapotranspiration and ultimately groundwater recharge. The SWB code also did not take into account potential changes in future vegetation or land-cover types, so the current land use was assumed static throughout the period of interest analyzed by the SWB code. In addition, routing of overland flow from precipitation was not accounted for in the SWB code; therefore, any effects this may have on the distribution of recharge are not simulated. The precipitation-runoff component of streamflow was not simulated in the groundwater-flow model, so that flow in streams was derived either from existing flow (at the boundaries of the intermediate model) or from discharge from the aquifer (base flow). Finally, the climate scenario used for this investigation should be viewed as one possible realization of the potential effects of climate change. There are many other climate scenarios available, which illustrate an array of potential climate-change outcomes that could have been used for this investigation. The focus of this investigation was to demonstrate a tool for assessing the potential effects of climate change on a hydrologic system, rather than to provide actual predictions of climate change.

\section{Summary}

The U.S. Geological Survey is providing an assessment of the availability and use of water resources, and the factors that affect them, throughout the United States. The Great Lakes Basin was chosen as the pilot study area to test new techniques and methods for evaluating water resources. These methods and techniques will then be transferred to other water-availability assessment areas. As part the Great Lakes Basin pilot study, a regional groundwater-flow model was constructed for the Lake Michigan Basin. This regional model was used as the framework for developing refined groundwater-flow models using telescopic mesh refinement and local grid refinement techniques.

The refined models developed illustrate the capability to use regional models to assess local-scale problems. The refined-model properties were taken directly from the regional model; however, only the upper six layers of the regional model were used for the refined-model analysis and were not refined further. Two separate lateral refinements were executed, creating models in an area of central Michigan, to ensure adequate refinement for headwater-stream simulation and reduce the computational burden: an intermediate-scale model with 500 feet by 500 feet cells covering an area of 454 square miles, and a local-scale model with 71.4 feet by 71.4 feet cells covering an area of 21.7 square miles.

Recharge for the refined models was estimated using the soil water balance (SWB) approach to provide initial recharge estimates for the regional model. Instead of using the same climate variables used for the regional model, climate inputs from an atmosphere-ocean coupled general circulation model (AOGCM) simulating high greenhouse-gas- emission conditions were used by the SWB code to estimate recharge.

The surface-water network used for the refined models was developed based on the National Hydrography Dataset (NHDPlus) datasets. Surface-water bodies were simulated using the general-head boundary package, and streams were simulated using a streamflow-routing package. The NHDPlus data were processed to compile streambed elevation and geometry into one data set. This data set was processed further 
to limit the extent of the network to only the intermediate and local models. A program was used to assign starting flows to streams that originated from outside the intermediate- model boundary. Because stream-width data were not available for every stream segment, an option was used that uses a power function to relate streamflow to stream depth and width when calculating the geometry of the stream. The refined models then were used to demonstrate stream-depletion scenarios and a potential climate-change scenario. Demonstrating stream depletion was done using four scenarios: a natural-conditions scenario with no pumping, a scenario with pumping from layer 1 , a scenario with pumping from layer 2 , and a scenario with pumping from layer 5 . Analyses of the scenarios indicate that pumping decreased streamflow in the test stream, with the wells pumping from the deeper layers having less of an effect than the well that was pumping from layer 1 and that was adjacent to the stream. Examining the scenarios through a mass-balance approach indicated that the net source of the water to the well ranged from 59 percent streamflow for the well in layer 1 to 50 percent streamflow for the well in layer 5 . The difference largely is made up by more water taken from surrounding watersheds (lateral flow) as the well was placed deeper.

A climate scenario was developed to provide one realization of effects of potential climate change on streamflows. This scenario used the recharge developed from the AOGCM inputs to the SWB model for the period 1991-2044 and was adjusted so that the current (1991-2005) period was more representative of actual climate. Results of the scenario indicate that recharge and related streamflow during the model-simulation period trended slightly upward toward the middle of the simulation period and trended downward from the middle to the end.

These scenarios illustrate the utility of taking a regional model and applying grid- refinement techniques to evaluate local-scale problems. The grid- refinement approach couples the local-scale to the larger-scale framework, thus helping ensure that boundary conditions are consistent and reasonable. Local-scale problems can be evaluated, such as determining whether enough streamflow can be maintained in a stream affected by pumping to support the aquatic ecosystem it supported prior to pumping. Likewise, competing uses among various water users can be better evaluated at a smaller scale. Using these various modeling tools that build upon an existing modeling framework means that many local-scale waterresource issues can be efficiently assessed by leveraging existing groundwater-flow models. 


\section{References Cited}

Arihood, L.D., 2009, Processing, analysis, and general evaluation of well-driller records for estimating hydrogeologic parameters of the glacial sediments in a ground-water flow model of the Lake Michigan Basin: Scientific Investigations Report 2008-5184, 26 p.

Calver, Ann, 2001, Riverbed permeabilities - information from pooled data: Ground Water, v. 39, no. 4, p. 546-553.

Environmental Systems Research Institute, Inc., 2008, ArcMap, GIS software, Version 9.2: Redlands, Calif.

Feinstein, D.T., Hunt, R.J., and Reeves, H.W., in press, Regional ground-water-flow model of the Lake Michigan Basin in support of Great Lakes Basin water availability and use studies: U.S. Geological Survey Scientific Investigations Report 2010-5109.

Grannemann, N.G., and Reeves, H.W., 2005, Great Lakes Basin water availability and use-A study of the National Assessment of Water Availability and Use Program: U.S. Geological Survey Fact Sheet 2005-3113, 4 p.

Harbaugh, A.W., Banta, E.R., Hill, M.C., and McDonald, M.G., 2000, MODFLOW-2000, the U.S. Geological Survey modular ground-water model-User guide to modularization concepts and the Ground-Water Flow Process: U.S. Geological Survey Open-File Report 00-92, 121 p.

Harbaugh, A.W., 2005, MODFLOW-2005-The U.S. Geological Survey modular ground-water model-The groundwater flow process: U.S. Geological Survey Techniques and Methods 6-A16 [variously paged].

Hayhoe, K., Wake, C., Anderson, B., Liang, X.-L., Maurer, E., Zhu, J., Bradbury, L., DeGaetano, A., Stoner A., and Wuebbles, D., 2008, Regional climate change projections for the northeast USA: Mitigation and Adaptation Strategies for Global Change, v. 13, no. 5-6, p. 425-436.

Holtschlag, D.J., 2009, Application guide for AFINCH (analysis of flows in networks of channels) described by NHDPlus: U.S. Geological Survey Scientific Investigations Report 2009-5188, 106 p.

Horizon Systems Corporation, 2006, NHDPlus HomeHorizon Systems Corporation NHDPlus database, accessed January 9, 2008, at http://www.horizon-systems.com/NHDPlus/.

Lampe, D.C., 2009, Hydrogeologic framework of bedrock units and initial salinity distribution for a simulation of ground-water flow for the Lake Michigan Basin: U.S. Geological Survey Scientific Investigations Report 2009-5060, 49 p.
Langevin, C.D., Shoemaker, W.B., and Guo, Weixing, 2003, MODFLOW-2000, the U.S. Geological Survey modular ground-water model-Documentation of the SEAWAT-2000 version with the variable-density flow process (VDF) and the integrated MT3DMS transport process (IMT): U.S. Geological Survey Open-File Report 2003-426, 43 p.

Leake, S.A., and Claar, D.V., 1999, Procedure and computer programs for telescopic mesh refinement using MODFLOW: U.S. Geological Survey Open-File Report 99-238, 53 p.

Leopold, L.B., Wolman, M.G., and Miller, J.P., 1992, Fluvial processes in geomorphology: Mineola, New York, Dover Publications, Inc., 522 p.

Maurer, E.P., Wood, A.W., Adam, J.C., Lettenmaier, D.P., and Nijssen, B., 2002, A long-term hydrologically based dataset of land surface fluxes and states for the conterminous United States: Journal of Climate, v. 15, no. 11, p. 3237-3251.

Mehl, S.W., and Hill, M.C., 2006, MODFLOW-2005, the U.S. Geological Survey modular ground-water model-Documentation of shared node local grid refinement (LGR) and the boundary flow and head $(\mathrm{BFH})$ package: U.S. Geological Survey Techniques and Methods 6-A12, 78 p.

Prudic, D.E., Konikow, L.F., and Banta, E.R., 2004, A new streamflow-routing (SFR1) package to simulate streamaquifer interaction with MODFLOW-2000: U.S. Geological Survey Open-File Report 2004-1042, 104 p.

Rumbaugh, J.O., and Rumbaugh, D.B., 2007, Groundwater Vistas, Version 5: Reinholds, Penn., Environmental Simulations, Inc., 375 p., accessed January 14, 2010, at http://www. groundwatermodels.com/Groundwater_Vistas.php.

The Nature Conservancy, 2008, ELOHA fact sheet, accessed June 29, 2009, at http://conserveonline.org/workspaces/ eloha/documents/brochure-english.

U.S. Geological Survey, 2006, National Elevation Dataset (NED) 30-meter Digital Elevation Models (DEMs): National Mapping Division, scale 1:24,000, accessed January 14, 2010, at http://gisdata.usgs.net/NED.

Westenbroek, S.M., Kelson, V.A., Dripps, W.R., Hunt, R.J., and Bradbury, K.R., 2010, SWB-A modified Thornthwaite-Mather soil-water-balance code for estimating groundwater recharge: U.S. Geological Survey Techniques and Methods 6-A31, 67 p. 



\section{Appendix 1. Surface-Water Network}

This appendix describes the processing steps used to convert stream information in the NHDPlus dataset to the SFR1 package format used to simulate streams in MODFLOW-LGR.

Streams in all model scenarios were simulated using the SFR1 package. Streamfeatures simulated with the SFR1 package are identified by reach and segment. A reach is defined as a portion of a stream that lies within a model cell. A segment is a group of connected reaches of a stream that can span multiple model cells (full description in Prudic and others, 2004). Segments and reaches must be ordered and numbered sequentially starting from the farthest upstream segment and terminating at the farthest downstream segment. The upstream segment must have a lower number than the downstream segment for flow to be correctly routed from the upstream segment to the downstream segment. The NHDPlus dataset was well suited for transitioning to the SFR1 package, because the geographic information system (GIS) stream coverage was organized as several different segments (stream arcs) correctly routed from upstream to downstream.

Several geospatial data-processing steps in ArcMap were executed to prepare the NHDPlus stream data for conversion to an SFR1 file. The first step was to join the stream network to the value-added attribute and the flow-line attribute tables (Horizon Systems Corporation, 2006) generated as part of the NHDPlus effort. These tables contain the stream-arc elevations and flow-routing information that ensure flow is correctly routed through the stream network. Once these data were appended to the stream segments, streams within the intermediatemodel area were extracted from the NHDPlus dataset within ArcMap (Environmental Systems Research Institute, Inc., 2008).

Streams that originated outside the outer boundary of the intermediate model were split at the intersection of the model boundary and stream segment. In that case, the information associated with the affected stream segment was updated to reflect the changes. Specifically, a new stream-segment length was calculated for the affected segment, and an elevation was calculated at the newly created boundary node of the stream segment. The elevation of the stream arc at the model boundary was calculated using the slope of the stream arc and the elevation of the known end of the stream arc from the NHDPlus data along with the new stream-arc length.

Flows into each segment that originated outside the external boundary of the intermediate model were estimated using the "Analysis of Flows In Networks of Channels" code (AFINCH) (Holtschlag, 2009). AFINCH estimates were needed because streamflow for those streams was not available from the regional model (and the SFR1 package was not used in the regional model). A flow of zero was assigned to all headwater segments. Flows were assigned to segments first by identifying the origin of each segment, which included creating a GIS coverage of points that represented either stream inflow or stream diversions (where a stream segment splits into two separate segments). All streams that originated outside the intermediate-model boundary and flowed into the model grid had to have an inflow point created. Once the flow calculated by AFINCH was assigned to the inflow points, a GIS coverage representing the model grid was created. The model-grid coverage was used by the ArcMap SFR1 creation program to locate the SFR reaches in the correct model cell and assign the stream elevation to each reach. Stream elevations in the NHDPlus data ensure proper flow routing, so these elevations were taken from the stream coverage and inserted into the model-grid coverage. This was done to make certain that the elevations were consistent between the model grid and the NHDPlus data. The ArcMap SFR1 creation tool then was executed, which (1) ordered and numbered all the stream segments and reaches according to SFR1 package requirements (Prudic and others, 2004), (2) assigned a starting flow to each segment that started at the model boundary, and (3) translated all the related GIS information into an SFR1 package formatted text file.

The SFR input file specifies if and by which technique stream stage is calculated using the ICALC variable (Prudic and others, 2004). In this study, ICALC was set equal to 3, which related streamflow to stream width and depth using a power function relation from Leopold 
and others (1992). The numerical constants CDPTH, FDPTH, AWDTH, and BWDTH (Prudic and others, 2004) were estimated using nonlinear regression of known widths and depths at five stream-gage locations within or near the intermediate-model area. Results of the regression yielded constants of $0.00083,0.48,0.63$, and 0.31 for CDPTH, FDPTH, AWDTH, and BWDTH respectively.

A beta version of MODFLOW-LGR was used in this study, which was able to route surface-water flow between the intermediate and local models (Steffen W. Mehl, U.S. Geological Survey, personal commun., 2008). To implement this version of MODFLOW-LGR, stream segments that cross the boundary of the intermediate and local models had to be split at the interface of the two models (fig. 1-1). This was done so that in a fully coupled LGR-simulation, flow from streams in the intermediate model would end at a segment at the boundary of the local model and be transferred to the analogous stream segment within the local model. Likewise, flow from the stream segments in the local model would end at the model boundary and be transmitted back across to the analogous stream segment within the intermediate model.

The procedure for generating the SFR1 package for the local model was the same as that for the intermediate model with the exception that starting flows were not assigned to streams that originate outside the local-model boundary because that flow was routed from the intermediate model to the local model. To allow for the proper routing of flow between model grids, two variables were added to item 4b of the SFR1 package (Prudic and others, 2004; Steffen W. Mehl, U.S. Geological Survey, personal commun., 2008). The first variable, AUX LGRGRID, was an integer value indicating from which grid the flow would enter. The second variable, AUX LGRSEG, was an integer indicating which stream segment the flow would exit from the first grid. For instance, the grid number and the segment number of the stream segment feeding into the local-model stream segment were appended to the end of item $4 \mathrm{~b}$ in the SFR1 file for local streams receiving flow from the parent grid (Prudic and others, 2004). For streams not receiving flow from the parent model, AUX LGRGRID and AUX LGRSEG were assigned the value 0 . This process was the same for streams in the parent model receiving flow from the local model; however, the stream segments in the parent model that were covered by the localmodel grid were given values of -1 for both AUX LGRGRID and AUX LGRSEG. A -1 value for those variables indicates no simulation of flow because these segments are redundant in that they are simulated by the local grid in the fully-coupled model. 


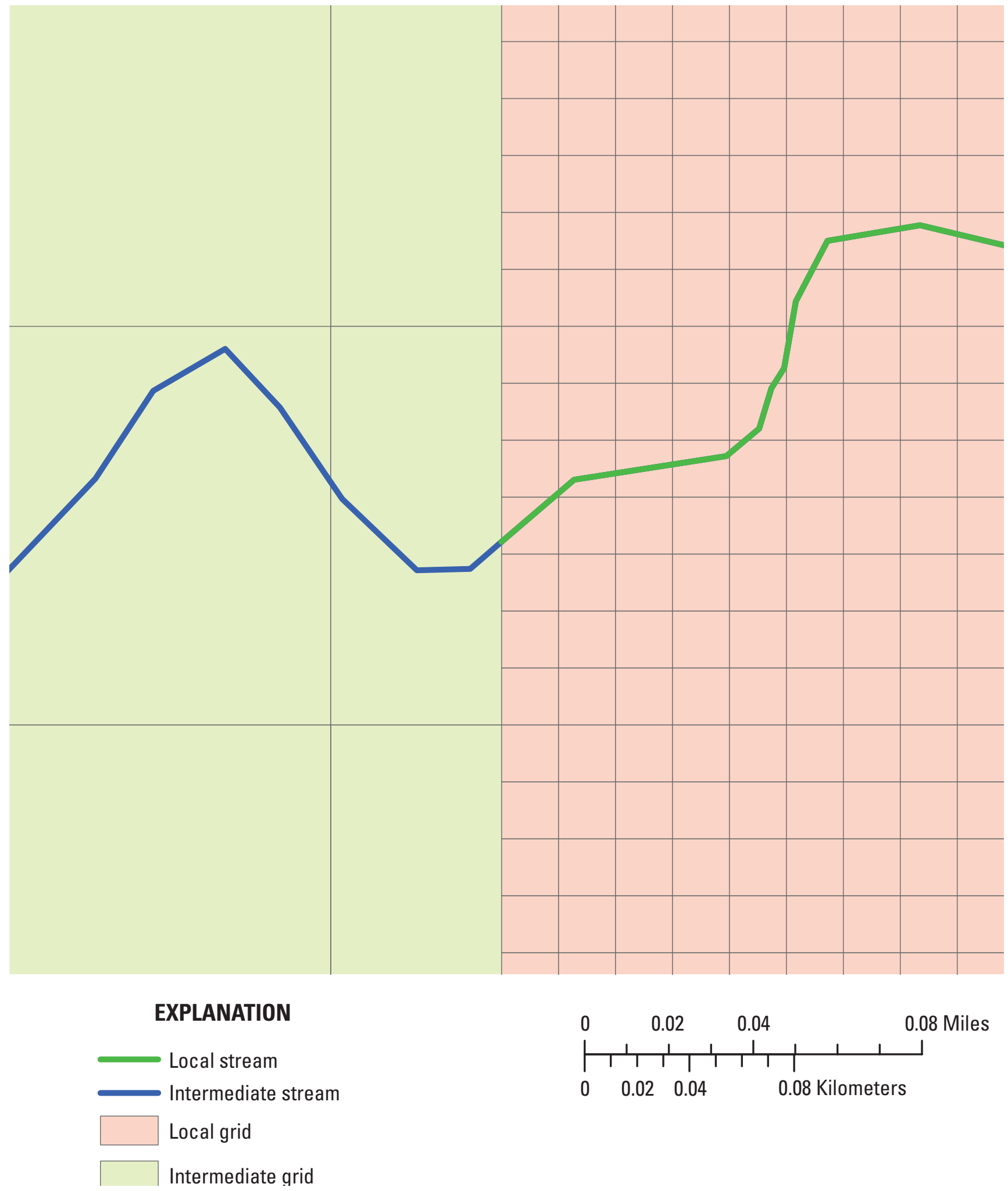

Figure 1-1. Stream-segment construction across the intermediate and local-model boundary. 




